\title{
A Facile Approach to Norbornene-annulated Cyclopentenones, A Novel Class of Tricyclodecadienones
}

\author{
Jie Zhu, Antonius J.H. Klunder and Binne Zwanenburg* \\ Department of Organic Chemistry, NSR Center for Molecular Structure, Design and Synthesis, \\ University of Nijmegen, Toernooiveld, 6525 ED Nijmegen, The Netherlands
}

\begin{abstract}
An efficient synthesis of norbornene annulated cyclopentenones $\underline{5}$ and $\underline{18}$ starting from readily available tricyclodecadienone carboxylic acid $2 a$ is described. Parent tricyclo[5.2.1. $\left.0^{2,6}\right]$ decadi-2(6),8-ene 5 , an hitherto unknown compound, has been obtained in good yield by subjecting bromide $7 \mathrm{~b}$ to base induced elimination or by oxidative deselenylation of $\underline{7 c}$. 5-Substituted analogues $\underline{18}$ are conveniently obtained from phenylselenide $3 c$ by stereoselective conjugate cuprate addition followed by oxidative elimination of the seleno group. Dehydrobromination of epoxy bromide $\underline{21}$ affords norbornene-annulated cyclopentadienone 22 which immediately undergoes stereoselective 1,4-addition at the strained $C_{2}-C_{6}$ enone moiety to give $\underline{23}$. These novel norbornene annulated cyclopentenones can be considered as the synthetic equivalent of 2-cyclopentynones.
\end{abstract}

\section{Introduction}

The tricyclo[5.2.1.0 $\left.0^{2,6}\right]$ decadienone system $\underline{1}$ constitutes a versatile synthetic equivalent of cyclopentadienone $^{1,2}$. Its rigid structure, the presence of a reactive $\alpha, \beta$-enone system and the ability of the tricyclic skeleton to undergo [4+2]-cycloreversion are instrumental in the synthesis of a variety of functionalized cyclopentenones with defined stereochemistry and chirality ${ }^{1,2}$. The endo-tricyclodecadienone system, racemic as well as enantiopure, is conveniently accessible via carboxylic acid $\underline{2 a}$, which in turn is readily available from the Diels-Alder adduct of benzoquinone and cyclopentadiene ${ }^{3}$.<smiles>O=C1C=CC2CC1C1C=CC2C1</smiles>

1<smiles>O=C1C=CC(C(=O)O)C2C=CC1C2</smiles>

2a $\mathrm{R}=\mathrm{H}$ 2b $\mathrm{R}=\mathrm{C}_{2} \mathrm{H}_{5}$<smiles>[X]C12C=CC(=O)C(C1)C1C=CC2C1</smiles>

3a $\quad X=B r$

3b $\mathrm{X}=\mathrm{OCH}_{3}$<smiles>O=C1C=CC2=C1C1C=CC2C1</smiles>

$\underline{4}$<smiles>O=C1CCC2=C3C=CC(C3)C1C2</smiles>

$\underline{5}$

In the preceding paper, the synthesis of a series of 6-substituted tricyclodecadienones $\underline{\mathbf{3}}$ starting from 2a employing Barton's radical chain decarboxylation methodology is described ${ }^{4}$. Bromodecarboxylation of $\underline{\mathbf{2 a}}$ appeared to be particularly suitable for a high yield synthesis of bridgehead bromide $\underline{\mathbf{3 a}}$. Dehydrobromination of $\underline{\mathbf{3 a}}$ using selected basic conditions is an efficient process to give elusive 
norbomene-annulated cyclopentadienone $\underline{4}$ as a transient intermediate in nearly quantitative yield. Although this cyclopentadienone is still too reactive to be isolated its bicyclic structure retards its [4+2]-dimerization to such an extent that nucleophilic conjugate addition and crossed Diels-Alder reactions can compete efficiently. This is exemplified by the alkaline methanolysis of bromide $\mathbf{3 a}$ which produces bridghead methyl ether $\underline{\mathbf{3 b}}$ in excellent yield $(>80 \%)$. The exclusive formation of $\underline{\mathbf{3 b}}$ shows that $\underline{\mathbf{4}}$ can be effectively intercepted by a nucleophile in a regio- and stereospecific conjugate addition involving the central $\mathrm{C}_{2}-\mathrm{C}_{6}$ enone moiety which is evidently more strained than the peripheral $\mathrm{C}_{4}-\mathrm{C}_{5}$ enone function. The efficient two step synthesis of $\underline{4}$ from acid $\underline{2 a}$ suggests that this sequence of steps may also be applicable to the synthesis of the interesting hitherto unknown positional isomer of $\underline{1} \mathrm{viz}$. tricyclo[5.2.1.0 $\left.0^{2,6}\right]$ deca-2(6),8-dien-3-one $\underline{\mathbf{5}}$. The absence of the peripheral enone moiety as present in $\mathbf{4}$ will probably lead to considerable chemical stability and accordingly it may be expected that this tricyclodecadienone $\underline{\mathbf{5}}$ is isolable despite its constrained $\mathrm{C}_{2}-\mathrm{C}_{6}$ enone system. In this paper the successful synthesis of $\underline{\mathbf{5}}$ and some of its derivatives is described.

\section{Results and discussion}

Norbornene-annulated cyclopentenone $\mathbf{5}$ is essentially the Diels-Alder adduct of cyclopentadiene and 2-cyclopentynone. Although this direct route to $\underline{\mathbf{5}}$ is obviously blocked by the non-availability of 2-cyclopentynone, even as a transient intermediate, the use of an appropriate synthetic equivalent may, however, circumvent this synthetic problem. Kienzle and Minder applied $\beta$-arylsulfonylcyclopentenones $\underline{6}$ for this purpose ${ }^{5}$. With cyclopentadiene the corresponding tricyclodecadienones $\mathbf{7 a}$ were obtained as an endolexo-mixture (2:1 ratio) in $60-80 \%$ yield (Scheme 1). Attempts to eliminate the arylsulfonyl group in $\underline{7 a}$ by a variety of basic reagents did not produce the desired ketone $\underline{\mathbf{5}}$ but only led to its isomer $\underline{1}(\mathrm{R}=\mathrm{H})$. Although the authors suggest that 1 is the result of $\beta, \gamma$-, and not of $\alpha, \beta$-elimination, involving the initial formation of $\underline{\mathbf{8}}$, this seems highly unlikely as the $\gamma$-hydrogen at $C_{5}$ is not activated at all. Most interestingly, reducing the $\mathrm{C}_{8}-\mathrm{C}_{9}$ double bond in $\underline{7}$ a and repeating the elimination procedure now smoothly converted $\underline{9}$ into the $\mathrm{C}_{2}-\mathrm{C}_{6}$ enone $\underline{\mathbf{1 0}}$ in $60-80 \%$ yield. (Scheme 1). This result indicates that the $\mathrm{C}_{8}-\mathrm{C}_{9}$

Scheme 1

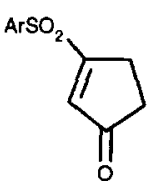

$\underline{6}$

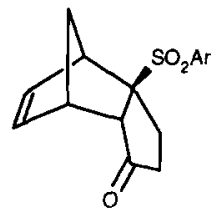

$\underline{7 a}$

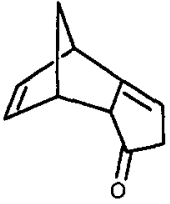

$\underline{8}$

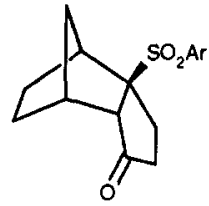

$\underline{9}$

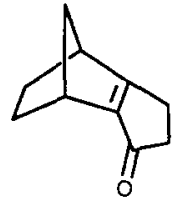

10

double bond in the $\beta$-elimination of sulfone 7a plays a decisive role in the product formation.

An effective route to 6-substituted tricyclodecenones $\mathbf{Z}$ is Barton's radical chain decarboxylation ${ }^{6}$ of the corresponding carboxylic acid $\underline{11}$ (Scheme 2). As was demonstrated for $\underline{\mathbf{3}}$ in the preceding paper ${ }^{4}$, both the 6-bromo and 6-selenyl compounds $\underline{\mathbf{7 b}}$ and $\underline{\mathbf{7 c}}$ are available using this methodology. Both compounds may then undergo $\alpha, \beta$-elimination to form $\underline{\mathbf{5}}$ either by base induced dehydrobromination or oxidative syn-deselenylation. These conversions may be much more effective than the elimination of sulfinic acid 
from sulfone $\underline{7}$.

The bromodecarboxylation of tricyclic acid $\underline{\mathbf{1 1}}$ which is readily available by lithium aluminum hydride reduction of tricyclic ester $\underline{\mathbf{2 b}}\left(\mathrm{R}=\mathrm{C}_{2} \mathrm{H}_{5}\right)^{1 \mathrm{i}, 7}$ and subsequent basic hydrolysis, was accomplished using essentially the same procedure as reported for the transformation of carboxylic acid $\mathbf{2 a}$ into enone bromide $\underline{\mathbf{3 a}}$. Conversion of $\underline{\mathbf{1 1}}$ into the corresponding acid chloride with oxalyl chloride, followed by treatment with the sodium salt of $\mathrm{N}$-hydroxypyridine-2-thione afforded the $\mathrm{N}$-acyloxypyridine-2-thione ester 12 which was immediately exposed to bromotrichloromethane at reflux temperature to give 6-bromo compound $\underline{7 \mathbf{b}}$ in an excellent overall yield of $91 \%$ (Scheme 2).

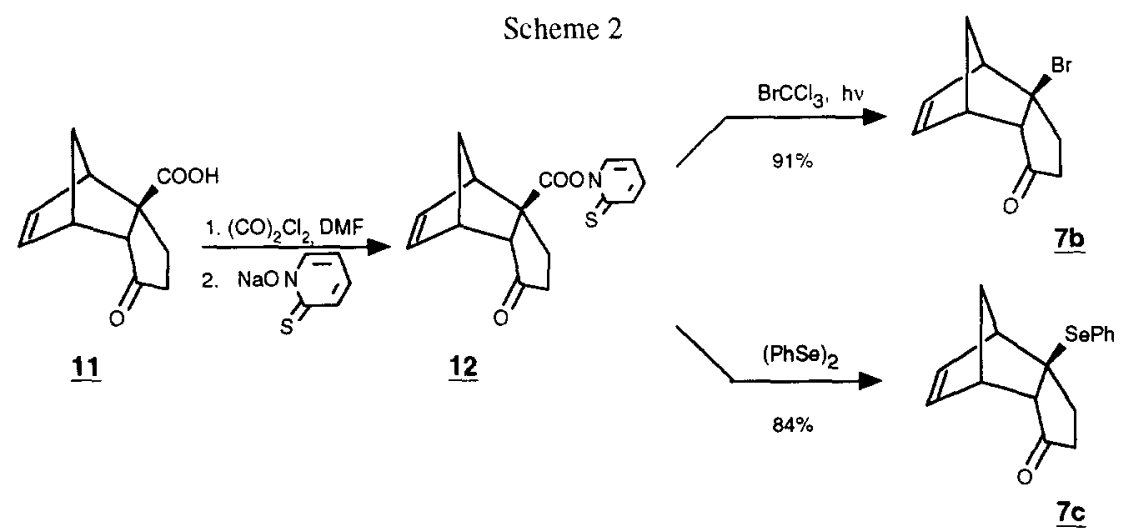

Phenylselenyldecarboxylation of $\underline{11}$ also proceeded smoothly with diphenyl selenide in toluene as the radical trapping agent. 6-Phenylselenyltricyclodecadienone $\underline{7 \mathrm{c}}$ was obtained in $84 \%$ yield as a nice crystalline material.

6-Bromotricyclodecenone $\underline{\mathbf{7 b}}$ showed similar reactivity towards triethylamine in methanol $(1: 4)$ as did as tricyclodecadienone bromide $\underline{\mathbf{3 a}}$. At room temperature hardly any elimination of bromide was observed whereas at reflux temperature the reaction was complete within 30 minutes. Capillary gas chromatography revealed the formation of three products in a ratio 12:4:1, which, on basis of their ${ }^{1} \mathrm{HNMR}$-spectra were identified as the desired enone $\underline{\mathbf{5}}$, and endo- and exo-tricyclodecadienone $\underline{\mathbf{1}}(\mathrm{R}=\mathrm{H})$ and $\underline{\mathbf{1 3}}$, respectively (Scheme 3 ). Pure $\underline{\mathbf{5}}$ was readily obtained in $60 \%$ yield by flash chromatography over

Scheme 3<smiles>O=C1CC[C@]2(Br)C3C=CC(C3)[C@H]12</smiles>

$\underline{7 b}$

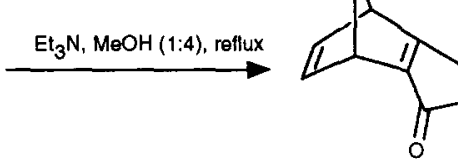

$\underline{5}(60 \%)$<smiles>O=C1C=C[C@H]2C[C@@H]1C1C=CC2C1</smiles>

$1(20 \%)$

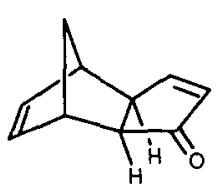

$13(5 \%)$

silica gel. The formation of endo- and exo-tricyclodecadienone ( $\underline{\mathbf{1}}$ and $\underline{\mathbf{1 3}})$ in this bromo-elimination of $\underline{\mathbf{7 b}}$ is readily explained by rearrangement of the initially formed $\underline{\mathbf{5}}$ involving the base induced enolization process depicted in Scheme 4. Deprotonation at $\mathrm{C}_{4}$ leads to the cyclopentadienolate intermediate which by 
Scheme 4<smiles>CC1C2C=CC1C(=CC1CC3CCC1C3C)C2=O</smiles>

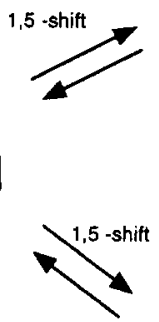<smiles>[O-]C1=C2C3C=CC(C3)C2C=C1</smiles>
endo-14<smiles></smiles>

exo-14

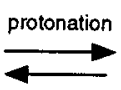

protonation

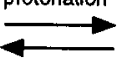

$\underline{13}$

a series of 1,5 proton shifts eventually forms either endo-14 or exo-14. Subsequent stereospecific protonation of these enolates at $\mathrm{C}_{2}$ then leads to observed mixture of endo- and exo-tricyclodecadienones $(\underline{1}$ and 13 ). The occurrence of such a base catalyzed process was conveniently demonstrated by treating $\underline{5}$ under identical conditions as applied by Kienzle and Minder $^{5}$ using diazabicyclo[5.4.0]undecene (DBU) in tetrahydrofuran. After stirring for 3 days quantitative conversion of $\underline{5}$ into a mixture of endo- $\underline{1}$ and exo- $\underline{13}$ in a ratio of 8:3 was observed. This result not only explains the failure of the Swiss group to isolate $\underline{\mathbf{5}}$ but also shows that the choice of the base used in the preparation of $\underline{\mathbf{5}}$ is crucial. The thermodynamic bias which is the reason for the rapid base induced isomerization of $\underline{\mathbf{5}}$ was substantiated by both force field (MM2) and semi-empirical (AM1) calculations ${ }^{8}$ (Table 1).

Table 1. Calculated heat of formation(AM1) and strain energy(MM2)

\begin{tabular}{|c|c|c|c|}
\hline & $\underline{\mathbf{1}}$ & $\underline{\mathbf{5}}$ & $\underline{\mathbf{1 3}}$ \\
\hline $\begin{array}{c}\text { Heat of formation (AM 1) } \\
\text { Kcal/mol }\end{array}$ & 27.62 & 41.13 & 25.85 \\
\hline $\begin{array}{c}\text { Strain energy (MM2) } \\
\text { Kcal/mol }\end{array}$ & 30.49 & 39.76 & 28.92 \\
\hline
\end{tabular}

After the successful synthesis of tricyclic enone $\underline{\mathbf{5}}$ using the non-nucleophilic base triethylamine, the question arose whether a more nucleophilic base system, such as potassium hydroxide in methanol could be used for the preparation of 6-methoxy-endo-tricyclodecenone $\underline{\mathbf{7 d}}$. At room temperature bromide $\underline{\mathbf{7 b}}$ rapidly reacted with this reagent to give $\underline{7 \mathbf{d}}$ in $90 \%$ yield (Scheme 5$)^{1 \mathrm{1i}, 7}$. No enone $\underline{\mathbf{5}}$ was detected in the product mixture. The formation of $\underline{\mathbf{7 d}}$ is clearly the result of rapid conjugate addition of methoxide to relatively strained $\mathrm{C}_{2}-\mathrm{C}_{6}$ enone moiety of initially formed $\underline{\mathbf{5}}$. This result already indicates the high reactivity of this central enone system in $\underline{\mathbf{5}}$ toward nucleophiles. Interestingly, no tricyclodecadienones $\underline{1}$ and $\underline{13}$ were observed showing that nucleophilic addition to $\underline{\mathbf{5}}$ is much more rapid than the enolization shown in Scheme 4.

The oxidative deselenylation is a syn-elimination reaction which generally proceeds at moderate 
Scheme 5

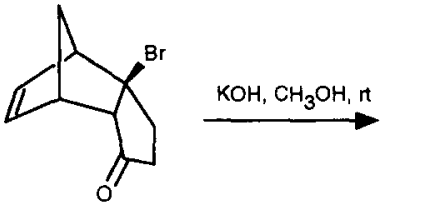

7b

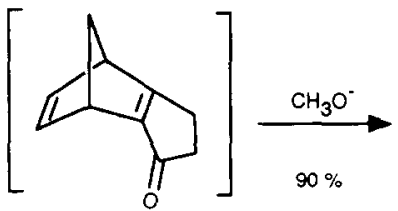

$\underline{5}$<smiles>CO[C@]12CCC(=O)[C@@H](C1)C1C=C[C@H]2C1</smiles>

$\underline{7 d}$

temperatures and in high yields 9 . Oxidation of selenide $\underline{7 \mathrm{c}}$ with sodium periodate at $5{ }^{\circ} \mathrm{C}$ using standard conditions fully conformed to this general picture. After $20 \mathrm{~min}$. the reaction was already complete to give tricyclodecadienone $\underline{\mathbf{5}}$ as a single product in $75 \%$ isolated yield (Scheme 6 ). No tricyclodecadienones $\underline{1}$ and

Scheme 6<smiles>C=CC1C2CC[C@@]1(S)CCC2=O</smiles>

$\underline{7 c}$

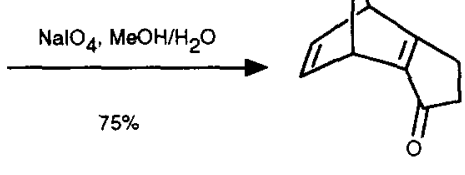

$\underline{5}$

$\underline{\mathbf{1 3}}$ were detected in the reaction mixture, confirming that base is needed for the isomerization of $\underline{\mathbf{5}}$ to these compounds.

It should be possible to extend the scope of the above methodology to the synthesis of derivatives of 5. One way to do so would be to use the enone system in either carboxylic acid $\underline{2 a}$ or 6-substituted tricyclodecadienones $\underline{\mathbf{3}}$ as a handle for derivatization. After the desired enone transformation, elimination of an appropriate leaving group at $\mathrm{C}_{6}$ would then give the desired $\mathrm{C}_{2}-\mathrm{C}_{6}$ enone moiety.

Tricyclic phenylselenide $\underline{\mathbf{3 c}}$ was selected to verify this approach as this compound is readily available in high yield from acid $\underline{\mathbf{2}}^{4}$ (Scheme 7 ). In view of the previous experiences with conjugate

Scheme 7<smiles>O=C1C=C[C@]2(O)CC1C=CC2C(=O)O</smiles>

$\underline{2 a}$

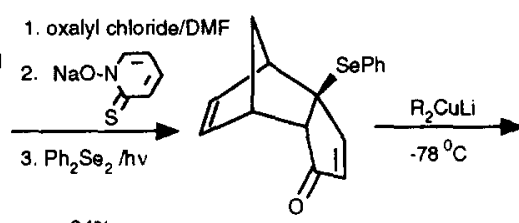

3c<smiles></smiles>

15

cuprate additions to tricyclodecadienones $\underline{1}^{10}$, this reaction was investigated for $\underline{3 c}$ using four different cuprates. 
The addition of dimethyl- and di-n-butylcuprate to $\underline{\mathbf{3}}$ proceeded smoothly and in both cases afforded a single addition product in excellent yield. Based on their spectral data which will be discussed below, structures $\underline{15 \mathbf{a}}$ and $\underline{15 \mathbf{b}}$ were assigned to these addition products (Scheme 7). Increasing the steric bulk of the nucleophile by using di-t-butylcuprate led again to a single addition product viz. $15 \mathrm{c}$ in a modest yield which is most likely due to the instability of the cuprate reagent. Subjecting $\underline{\mathbf{3 c}}$ to diphenylcuprate gave again a single 1,4-addition product, $1 \mathbf{1 5 d}$, and also a small amount of the 1,2-addition product.

The gross structures of the products $15 \mathbf{a}-\mathbf{d}$ were all deduced from their mass, IR, and NMR data. However, the unequivocal assignment of the configuration (endo or exo) of the newly introduced substitutent at $\mathrm{C}_{5}$ in 15 required a more detailed ${ }^{1} \mathrm{H}-\mathrm{NMR}$ analysis. Comparison of the ${ }^{1} \mathrm{H}-\mathrm{NMR}$ spectra of structures 15a-d with related tricyclodecenones viz. $\underline{\mathbf{1 6}}$ and $\underline{\mathbf{1 7}}^{10}$ revealed unambiguously the stereochemistry at $\mathrm{C}_{5}$ in $\underline{\mathbf{1 5}}$ (Table 2). All tricyclodecenones $\underline{\mathbf{1 6}}$ and $\underline{\mathbf{1 7}}$ having $\mathrm{C}_{5}$ endo-protons exhibit

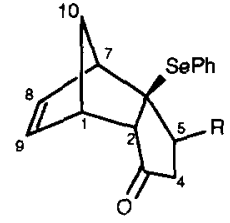

$\underline{15}$

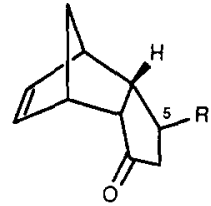

16

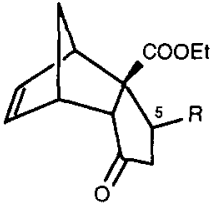

17

Table 2. chemical shift of selected protons in $\underline{\mathbf{1 5}}, \underline{\mathbf{1 6}}$ and $\underline{\mathbf{1 7}}$

\begin{tabular}{|c|c|c|c|c|c|}
\hline & & \multicolumn{4}{|c|}{$\delta(\mathrm{ppm})$} \\
\hline \multicolumn{2}{|r|}{ compound } & $\mathrm{H}_{5-\mathrm{exo}}$ & $\mathrm{H}_{5 \text {-endo }}$ & \multicolumn{2}{|c|}{$\mathrm{H}_{8}$ and $\mathrm{H}_{9}$} \\
\hline $\begin{array}{r}15 \\
\underline{\mathbf{b}} \\
\underline{\mathbf{c}} \\
\underline{\mathbf{d}}\end{array}$ & $\begin{aligned} \mathrm{R}= & \text { endo }-\mathrm{Me} \\
& \text { endo }-\mathrm{n}-\mathrm{Bu} \\
& \text { endo }-\mathrm{t}-\mathrm{Bu} \\
& \text { endo }-\mathrm{Ph}\end{aligned}$ & $\begin{array}{l}2.76 \\
2.60 \\
2.77 \\
3.99\end{array}$ & & $\begin{array}{l}6.11 \\
6.09 \\
6.13 \\
5.69 \\
\end{array}$ & $\begin{array}{l}6.31 \\
6.27 \\
6.35 \\
6.05 \\
\end{array}$ \\
\hline$\underline{16} \frac{\underline{a}}{\frac{b}{c}}$ & $\begin{aligned} \mathrm{R}= & \text { exo }-\mathrm{Me} \\
& \text { exo }-\mathrm{n}-\mathrm{Bu} \\
& \text { exo }-\mathrm{Ph} \\
& \text { endo }-\mathrm{Me}\end{aligned}$ & 2.40 & $\begin{array}{l}1.86 \\
1.68 \\
2.92\end{array}$ & $\begin{array}{l}6.12 \\
6.14 \\
6.26 \\
6.01\end{array}$ & $\begin{array}{l}6.16 \\
6.15 \\
6.30 \\
6.21\end{array}$ \\
\hline $\begin{array}{r}\underline{17} \frac{\mathbf{a}}{\underline{b}} \\
\frac{\underline{c}}{\underline{d}} \\
\underline{\underline{e}}\end{array}$ & $\begin{aligned} \mathrm{R}= & \text { exo }-\mathrm{Me} \\
& \text { exo }-\mathrm{n}-\mathrm{Bu} \\
& \text { exo }-\mathrm{Ph} \\
& \text { endo }-\mathrm{Me} \\
& \text { endo }-\mathrm{n}-\mathrm{Bu} \\
& \text { endo }-\mathrm{Ph}\end{aligned}$ & $\begin{array}{l}2.44 \\
2.31 \\
3.97\end{array}$ & $\begin{array}{l}2.04 \\
1.86 \\
3.26\end{array}$ & $\begin{array}{l}6.20 \\
6.18 \\
6.42 \\
6.16 \\
6.14 \\
5.79 \\
\end{array}$ & $\begin{array}{l}6.30 \\
6.30 \\
6.42 \\
6.35 \\
6.32 \\
6.12 \\
\end{array}$ \\
\hline
\end{tabular}

proton signals at a considerably higher field (lower shift value) than the $\mathrm{C}_{5}$ exo-protons in the related structures. This phenomenon is the result of effective shielding of the endo- $\mathrm{C}_{5}$ protons by the $\mathrm{C}_{8}-\mathrm{C}_{9}$ double bond. The observation that for $15 \mathbf{a}-\mathbf{d}$ the $\mathrm{C}_{5}$ protons are found at relatively lower field (higher shift value) proves their endo-stereochemistry (endo-R). Additional evidence for the correctness of this assignment is derived from the strong shielding effect exhibited by the $\mathrm{C}_{5}$ endo-phenyl group on the $\mathrm{C}_{8}$ and $\mathrm{C}_{9}$ olefinic 
protons in $17 \mathrm{f}$ and $\underline{15 \mathrm{~d}}$. In $17 \mathrm{c}$ which contains an $\mathrm{C}_{5}$-exo-phenyl substituent these olefinic protons absorb at considerably lower field (higher shift value). At a later stage of this project definite proof of the correctness of this ${ }^{1} \mathrm{HNMR}$ analysis was obtained from an X-ray diffraction analysis of $\underline{15 a}$ the result of which is depicted in figure $1^{11}$.

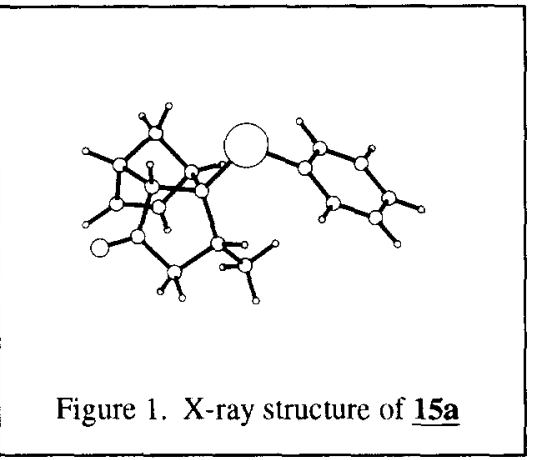

The complete endo-selectivity in combination with the high yields and relatively fast reaction rates observed for the cuprate addition to $\underline{3 c}$ is quite surprising as the endo-face of the endo-tricyclodecadienone system is severely hindered by the $\mathrm{C}_{8}-\mathrm{C}_{9}$ ethene bridge which generally results in predominant exo-addition. It is evident that the bulky phenylselenyl group at $\mathrm{C}_{6}$ may severely hinder or even block conjugate addition from the exo-face of $\underline{3 c}$ but this should at least be reflected in lower reaction rates and lower yields. Detailed studies to uncover the true nature of this cuprate addition to $\underline{\mathbf{3 c}}$ are currently underway and will be reported in due course. From a synthetic point of view this directing effect of the phenylselenyl group is highly rewarding.

The oxidative deselenation of $\underline{\mathbf{1 5}}$ was carried out as described above for the synthesis of $\underline{\mathbf{5}}$ from $\underline{\mathbf{7}}$. By stirring 15a-d with sodium periodate in methanol a smooth elimination was observed in all cases to afford the corresponding tricyclodecadienones 18a-d in yields of $c a .80 \%$ (Scheme 8).

Scheme 8

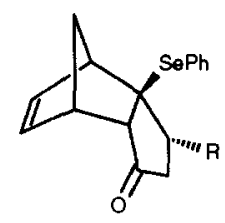

$\underline{15}$

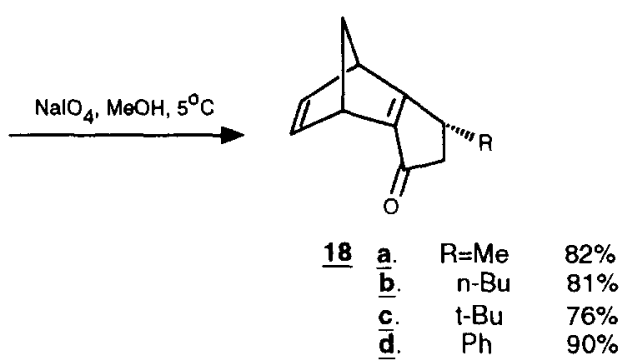

The successful synthesis of norbornene-annulated cyclopentenones $\underline{5}$ and $\underline{18}$ was a reason to consider this methodology for the preparation of norbornene-annulated cyclopentenone epoxide 22 (Scheme 9). Cyclopentenone epoxide $\underline{\mathbf{2 2}}$ is a fascinating compound for which an unusual chemical reactivity is expected on basis of the unique combination of an epoxide ring, a vinyl system and a ketone function within in a compact, small ring system. In recent papers, a first general synthesis of some simply substituted cyclopentadienone epoxides and their reactions with nucleophilic reagents was reported ${ }^{12}$. The 
synthetic potential of these epoxides for natural product synthesis was demonstrated by the preparation of epi-pentenomycin ${ }^{1 \mathrm{1}, 13}$.

A direct route to $\underline{\mathbf{2 2}}$ would be the regioselective epoxidation of the enone moiety in tricyclic bromide $\underline{3 a}$ to give epoxy bromide 21 followed by dehydrobromination. However, attempts to obtain $\underline{21}$ by alkaline epoxidation of tricyclic bromide $\underline{3 a}$ using standard methods did not give satisfactory results. Epoxide $\underline{21}$ was obtained in only $40 \%$ yield due to the base sensitivity of bromide $\underline{3 a}$. As oxidation of selenium by hydrogen peroxide is a fast process we did not try such an epoxidation for $\underline{3 \mathbf{c}}$.

An alternative route to epoxy bromide $\underline{21}$ starts from tricyclic epoxide ester $\underline{19}$ which is produced from ester $\underline{\mathbf{2 b}}$ in more than $90 \%$ yield by alkaline epoxidation ${ }^{\mathrm{la}, \mathrm{g}}$ (Scheme 9). Basic hydrolysis using

Scheme 9

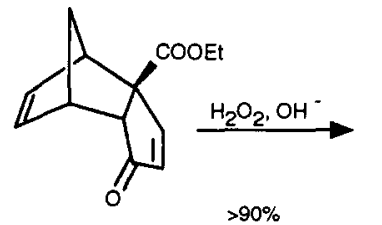

$\underline{2 b}$<smiles>CCOC(=O)C12CCC(CC1=O)C2C(=O)O</smiles>

$\underline{19}$

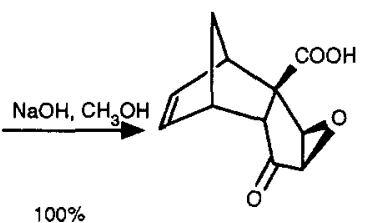

$\underline{20}$

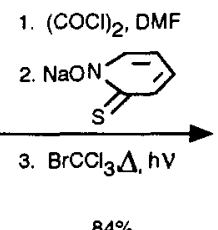

$84 \%$

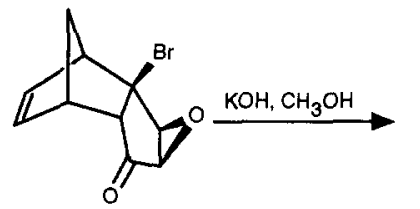

$\underline{21}$

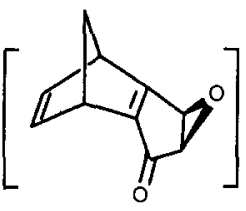

$\underline{22}$

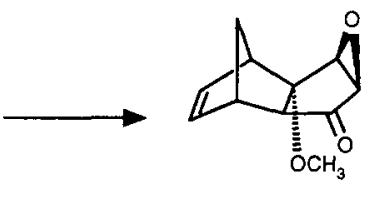

$71 \%$

$\underline{23}$

sodium hydroxide in methanol afforded epoxy acid $\underline{\mathbf{2 0}}$ in quantitative yield. Barton halodecarboxylation of $\underline{20}$ using essentially the same procedure as described earlier for the synthesis of $\underline{\mathbf{7 b}}$, gave $\underline{\mathbf{2 1}}$ in $84 \%$ yield. Applying triethylamine as the base to effect dehydrobromination of $\underline{\mathbf{1 1}}$ under a variety of conditions led only to complex mixtures. No cyclopentadienone epoxide $\underline{\mathbf{2 2}}$ was detected among the products. When a more nucleophilic reagent was applied, such as potassium hydroxide in methanol, a methoxy substituted epoxide was isolated in $71 \%$ yield. Again there were no indications of the presence of $\underline{\mathbf{2 2}}$ in the reaction mixture showing that this annulated cyclopentadienone epoxide is apparently too reactive to be isolated under these nucleophilic conditions ${ }^{14}$. Analysis of the ${ }^{1}$ HNMR spectra suggested structure $\underline{\mathbf{2 3}}$ for the newly formed epoxy ketone. The formation of this endo-6-methoxy-exo-tricyclodecenone epoxide from exo-6-bromo-endo-tricyclodecenone epoxide 21 proves the intermediacy of norbornene-annulated cyclopentenone epoxide $\underline{\mathbf{2}}$ which under the reaction conditions rapidly undergoes stereospecific conjugate addition of methanol at its endo-face. In the preceding paper, it was reported that methanol addition to norbornene annulated cyclopentadienone $\underline{\mathbf{4}}$ is also a stereospecific process to give exclusively

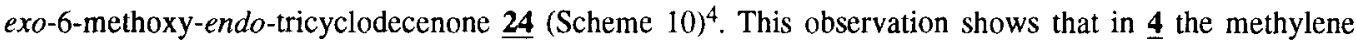
bridge exerts less steric hindrance to the incoming nucleophile than the $\mathrm{C}_{8}-\mathrm{C}_{9}$ ethylene bridge. The complete inversion of stereochemistry observed for the methoxylation to epoxide $\underline{\mathbf{2 2}}$ illustrates the subtlety of this 'bridge effect' on the facial stereoselectivity of conjugate addition reactions to these 
Scheme 10

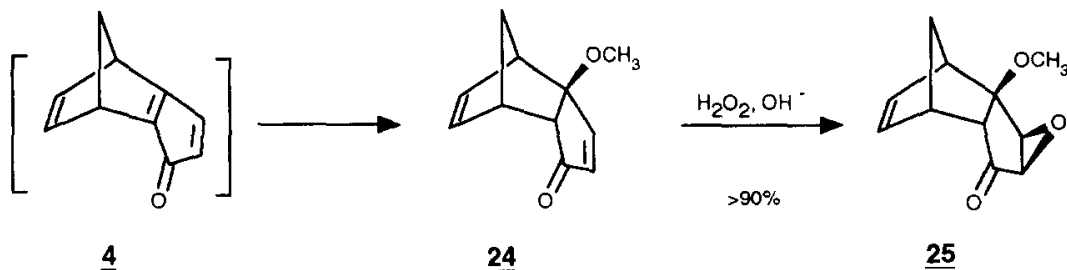

tricyclodecadienones. The presence of a relative small epoxide function at the exo-face as in $\underline{\mathbf{2 2}}$ exerts enough steric bulk to completely outweigh the directing effect of the bridges.

Unambiguous proof for the correctness of structure $\underline{23}$ was obtained from the alkaline epoxidation of $\underline{\mathbf{2 4}}^{4}$ which gave exo-6-methoxy-endo-tricyclodecadienone epoxide $\mathbf{2 5}$ in almost quantitative yield (Scheme 10). This epoxide, which structure was unequivocally established by comparison of its ${ }^{1}$ HNMR-data with those of tricyclic exo-epoxides $\underline{\mathbf{1 9}}, \underline{\mathbf{2 0}}$ and $\underline{\mathbf{2 1}}^{15}$, was not identical with tricyclic epoxide $\underline{\mathbf{2 3}}$.

The results described above indicate that the synthesis of norbornene annulated cyclopentenones including parent tricyclodeca-2(6),8-dien-3-one $\underline{\mathbf{5}}$ can be accomplished starting from readily available carboxylic acid 2a.

\section{Experimental}

\section{General remarks}

Melting points were measured with a Reichert Thermopan microscope and are uncorrected. IR spectra were recorded on a Perkin-Elmer 298 infrared spectrophotometer. ${ }^{1} \mathrm{H}$ and ${ }^{13} \mathrm{C}$-NMR spectra were recorded on a Bruker AM-400 spectrophotometer, using TMS as an internal standard. For mass spectra a double focussing VG 7070E mass spectrometer was used. Capillary GC analyses were performed using a Hewlett-Packard 5890A gas chromatograph, containing a cross-linked methyl silicone column (25m). Flash chromatography were carried out at a pressure of ca. $1.5 \mathrm{bar}$, a column length of $15-25 \mathrm{~cm}$ and a column diameter of $1-4 \mathrm{~cm}$, using Merck Kieselgel $60 \mathrm{H}$. Elemental analyses were performed on a Carlo Erba Instruments CHNS-O 1108 Elemental analyzer. All solvents used were dried and distilled according to the standard procedures.

\section{6-Bromo-endo-tricyclo/ $\left.5.2 .1 .0^{2,6}\right]$ deca-8-en-3-one $7 \mathbf{b}$}

A solution of acid 11 (192 $\mathrm{mg}, 1 \mathrm{mmole})$ in benzene $(5 \mathrm{ml})$ was treated with oxalyl chloride $(0.3 \mathrm{ml})$ and a drop of dimethylformamide. After stirring for $2 \mathrm{hrs}$ at room temp. with protection from moisture, the solvent and excess oxalyl chloride were evaporated and the residual acid chloride was used as such.

A solution of acid chloride ( $1 \mathrm{mmole})$ in benzene $(5 \mathrm{ml})$ was added dropwise $(15 \mathrm{~min}$.) to a dried, stirred suspension of N-hydroxypyridin-2-thione sodium salt (190 $\mathrm{mg}, 1.2 \mathrm{mmole})$ in refluxing bromotrichloromethane while irradiating with a $250 \mathrm{w}$ tungsten lamp in an inert atmosphere. After completion of the addition, the reaction mixture was cooled to room temp. and evaporated to dryness. The crude product was purified by flash chromatography over silica gel to give pure $\underline{7 \mathbf{b}}(200 \mathrm{mg}, 90 \%)$ as a 
colorless oil.

7b: ${ }^{1} \mathrm{H}-\mathrm{NMR}\left(400 \mathrm{MHz}, \mathrm{CDCl}_{3}\right.$ ): $\delta 6.25-6.20\left(\mathrm{~m}, 2 \mathrm{H}, \mathrm{H}_{8}\right.$ and $\mathrm{H}_{9}$ ), 3.41 (brs, $1 \mathrm{H}, \mathrm{H}_{1}$ or $\mathrm{H}_{7}$ ), 3.32 (d, $\mathrm{J}_{1,2}=4.5 \mathrm{~Hz}, 1 \mathrm{H}, \mathrm{H}_{2}$ ), 3.25 (brs, $1 \mathrm{H}, \mathrm{H}_{1}$ or $\mathrm{H}_{7}$ ), 2.73-2.65, 2.61-2.52, 2.35-2.25 and 2.15-1.91 (4 x m, $4 \mathrm{H}$, $\mathrm{H}_{4}$ and $\left.\mathrm{H}_{5}\right), 2.26 \mathrm{~A}$ of $\mathrm{AB}\left(\mathrm{d}, \mathrm{J}_{10 \mathrm{a}, 10 \mathrm{~s}}=8.9 \mathrm{~Hz}, 1 \mathrm{H}, \mathrm{H}_{10 \mathrm{~s}}\right), 1.91 \mathrm{~B} \mathrm{~A}$ of $\mathrm{AB}\left(\mathrm{d}, \mathrm{J}_{10 \mathrm{a}, 10 \mathrm{~s}}=8.9 \mathrm{~Hz}, 1 \mathrm{H}, \mathrm{H}_{10 \mathrm{a}}\right)$. ${ }^{13} \mathrm{C}-\mathrm{NMR}$ (100 MHz, $\mathrm{H}$-dec., $\mathrm{CDCl}_{3}$ ): $\delta 216.5$ (quat.), 138.0/134.5 (tert.), 71.1 (quat.), 66.0/57.9 (tert.), 52.7 (sec.), 47.0 (tert.), 41.8/37.4 (sec.). IR $\left(\mathrm{CH}_{2} \mathrm{Cl}_{2}\right):$ v 3100-3020 (C-H, unsat.), 3010-2820 (C-H, sat.), $1730(\mathrm{C}=\mathrm{O}) \mathrm{cm}^{-1}$. CI/MS: m/e (\%) 229/227 (0.1/0.1, $\left.\mathrm{M}^{+}+1\right), 163 / 161\left(12 / 13, \mathrm{M}^{+}+1-\mathrm{Br}\right), 147(12$, $\left.\mathrm{M}^{+}-\mathrm{C}_{5} \mathrm{H}_{6}\right), 66\left(29, \mathrm{C}_{5} \mathrm{H}_{6}{ }^{+}\right)$. EU/HRMS m/e: 227.0071 [calc.for $\mathrm{C}_{10} \mathrm{H}_{12} \mathrm{O}^{79} \mathrm{Br}\left(\mathrm{M}^{+}+1\right): 227.0072$ ].

\section{6-Phenylselenyl-endo-tricyclo[5.2.1.0 2,6$]$ deca-8-en-3-one 7c}

A solution of acid 11 (192 $\mathrm{mg}, 1 \mathrm{mmole})$ in benzene $(5 \mathrm{ml})$ was treated with oxalyl chloride $(0.3 \mathrm{ml})$ and a drop of dimethylformamide. After stirring for 2 hrs at room temp. with protection from moisture, the solvent and excess oxalyl chloride were evaporated and the residual acid chloride used as such.

A solution of acid chloride ( $1 \mathrm{mmole}$ ) in toluene $(5 \mathrm{ml}$ ) was added dropwise (15 min.) to a dried, stirred suspension of $\mathrm{N}$-hydroxypyridin-2-thione sodium salt (190 $\mathrm{mg}, 1.2 \mathrm{mmole}$ ) in refluxing toluene $(10 \mathrm{ml})$ containing $2 \mathrm{mmol}$ of diphenyl diselenide while irradiating with a $250 \mathrm{w}$ tungsten lamp in an inert atmosphere. After completion of the addition, the reaction mixture was cooled to room temp. and evaporated to dryness. The crude product was purified by flash chromatography (n-hexane /EtOAc $=9 / 1$ ) over silica gel to give pure $\mathbf{7 c}(260 \mathrm{mg}, 84 \%)$ as a white solid.

7c: m.p.: 101-103 ${ }^{\circ} \mathrm{C}$ (diisopropyl ether). ${ }^{1} \mathrm{H}-\mathrm{NMR}\left(400 \mathrm{MHz}, \mathrm{CDCl}_{3}\right): \delta 7.68-7.32(\mathrm{~m}, 5 \mathrm{H}, \mathrm{Ph}-\mathrm{H})$, 6.20-6.16 ( $\mathrm{m}, 2 \mathrm{H}, \mathrm{H}_{8}$ and $\left.\mathrm{H}_{9}\right), 3.24$ and $3.19\left(2 \mathrm{x}\right.$ brs, $2 \mathrm{H}, \mathrm{H}_{1}$ and $\left.\mathrm{H}_{7}\right), 2.91\left(\mathrm{~d}, \mathrm{~J}_{1,2}=4.5 \mathrm{~Hz}, 1 \mathrm{H}, \mathrm{H}_{2}\right)$, 2.46-2.26 (m, $\left.2 \mathrm{H}, \mathrm{H}_{4}\right), 2.24 \mathrm{~A}$ of $\mathrm{AB}\left(\mathrm{d}, \mathrm{J}_{10 \mathrm{a}, 10 \mathrm{~s}}=8.7 \mathrm{~Hz}, 1 \mathrm{H}, \mathrm{H}_{10 \mathrm{~s}}\right), 2.08-2.00$ and 1.94-1.76 $(2 \mathrm{x} \mathrm{m}, 2 \mathrm{H}$, $\left.\mathrm{H}_{5}\right), 1.77 \mathrm{~B}$ A of $\mathrm{AB}\left(\mathrm{d}, \mathrm{J}_{10 \mathrm{a} .10 \mathrm{~s}}=8.7 \mathrm{~Hz}, \mathrm{lH}, \mathrm{H}_{\mathrm{lOa}}\right) .{ }^{13} \mathrm{C}-\mathrm{NMR}\left(100 \mathrm{MHz}, \mathrm{H}-\right.$ dec., $\left.\mathrm{CDCl}_{3}\right): \delta 218.5$ (quat.), 137.0/136.6/135.9/129.2 (tert.), 128.9 (quat.), 128.7/62.4 (tert.), 58.0 (quat.), 53.8 (tert.), 52.4 (sec.), 47.0 (tert.), 41.5/33.3 (sec.). IR ( $\left.\mathrm{CH}_{2} \mathrm{Cl}_{2}\right):$ v 3100-3020 (C-H, unsat.), 3010-2820 (C-H, sat.), $1725(\mathrm{C}=\mathrm{O}) \mathrm{cm}^{-1}$. CI/MS: $\mathrm{m} / \mathrm{e}(\%) 304\left(0.5, \mathrm{M}^{+}\right), 238\left(44, \mathrm{M}^{+}-\mathrm{C}_{5} \mathrm{H}_{6}\right), 66\left(10, \mathrm{C}_{5} \mathrm{H}_{6}{ }^{+}\right)$. EL/HRMS m/e: 304.0366 [calc.for $\left.\mathrm{C}_{16} \mathrm{H}_{16} \mathrm{O}^{80} \mathrm{Se}\left(\mathrm{M}^{+}\right): 304.0366\right]$.

endo-Tricyclo $\left.15.2 .1 .0^{2,6}\right]$ deca-2(6),8-dien-3-one 5 and endo- and exo-tricyclo[5.2.1.0 $\left.0^{2,6}\right]$ deca-4,8-dien-3one 1 and $\mathbf{1 3}^{17}$

A solution of $\underline{\mathbf{7 b}}(60 \mathrm{mg})$ in methanol $(8 \mathrm{ml})$ and $\mathrm{Et}_{3} \mathrm{~N}(2 \mathrm{ml})$ was refluxed for $30 \mathrm{~min}$. Removal of the solvent followed by dissolution of the residue in n-hexane/ethyl acetate (3/1) and subsequent filtration gave, after drying $\left(\mathrm{MgSO}_{4}\right)$ and concentration, a mixture $(40 \mathrm{mg})$ of $\underline{\mathbf{5}}, \underline{1}$ and $\underline{\mathbf{1 3}}$ in 12:4:1 ratio (according to $\mathrm{GC}$ and NMR). Pure $\underline{\mathbf{5}}$ was obtained by flash chromatography (n-hexane $/ \mathrm{EtOAc}=6 / 1$ ).

5: ${ }^{1} \mathrm{H}-\mathrm{NMR}\left(400 \mathrm{MHz}, \mathrm{CDCl}_{3}\right.$ ): $\delta 6.88 \mathrm{~A}$ of $\mathrm{AB}\left(\mathrm{dd}, \mathrm{J}_{8,9}=5.0 \mathrm{~Hz}, \mathrm{~J}_{1,9}\right.$ resp. $\mathrm{J}_{7,8}=3.2 \mathrm{~Hz}, 1 \mathrm{H}, \mathrm{H}_{8}$ or $\mathrm{H}_{9}$ ), $6.79 \mathrm{~B}$ of $\mathrm{AB}$ (dd, $\mathrm{J}_{8,9}=5.0 \mathrm{~Hz}, \mathrm{~J}_{1,9}$ resp. $\mathrm{J}_{7,8}=3.3 \mathrm{~Hz}, 1 \mathrm{H}, \mathrm{H}_{8}$ or $\mathrm{H}_{9}$ ), 3.76 and $3.61\left(2 \mathrm{x}\right.$ brs, $2 \mathrm{H}, \mathrm{H}_{1}$ and $\mathrm{H}_{7}$ ), 2.84-2.50 (m, $4 \mathrm{H}, \mathrm{H}_{4}$ and $\left.\mathrm{H}_{5}\right), 2.47$ and $2.39 \mathrm{AB} \times 2\left(2 \times \mathrm{d}, \mathrm{J}_{10 \mathrm{~s}, 10 \mathrm{a}}=6.8 \mathrm{~Hz}, 2 \mathrm{H}, \mathrm{H}_{10}\right) .{ }^{13} \mathrm{C}-\mathrm{NMR}(100$ $\mathrm{MHz}, \mathrm{CDCl}_{3}$ ): $\delta$ 203.2/199.4/159.4 (quat.), 144.6/141.6 (tert.), 74.6 (sec.), 51.1/44.9 (tert.), 41.2/26.3 (sec.). IR $\left(\mathrm{CH}_{2} \mathrm{Cl}_{2}\right): v$ 3010-2860 (C-H, sat.), $1675(\mathrm{C}=\mathrm{O}) \mathrm{cm}^{-1}$. EI/MS: m/e (\%) $146\left(100, \mathrm{M}^{+}\right), 66(21$, $\mathrm{C}_{5} \mathrm{H}_{6}{ }^{+}$). EI/HRMS m/e: 146.0732 [calc.for $\mathrm{C}_{10} \mathrm{H}_{10} \mathrm{O}\left(\mathrm{M}^{+}\right):$: 146.0732]. 1: ${ }^{1} \mathrm{H}-\mathrm{NMR}\left(400 \mathrm{MHz}, \mathrm{CDCl}_{3}\right): \delta 7.38\left(\mathrm{dd}, \mathrm{J}_{4.5}=5.7 \mathrm{~Hz}, \mathrm{~J}_{5.6}=2.6 \mathrm{~Hz}, 1 \mathrm{H}, \mathrm{H}_{5}\right), 5.96\left(\mathrm{~d}, \mathrm{~J}_{4.5}=5.7 \mathrm{~Hz}, 1 \mathrm{H}\right.$, 
$\left.\mathrm{H}_{4}\right), 5.94 \mathrm{~A}$ of $\mathrm{AB}\left(\mathrm{dd}, \mathrm{J}_{8,9}=5.6 \mathrm{~Hz}, \mathrm{~J}_{1,9}\right.$ resp. $\mathrm{J}_{7,8}=2.9 \mathrm{~Hz}, 1 \mathrm{H}, \mathrm{H}_{8}$ or $\left.\mathrm{H}_{9}\right), 5.78 \mathrm{~B}$ of $\mathrm{AB}\left(\mathrm{dd}, \mathrm{J}_{8,9}=5.6 \mathrm{~Hz}\right.$, $\mathrm{J}_{1,9}$ resp. $\mathrm{J}_{7,8}=3.0 \mathrm{~Hz}, 1 \mathrm{H}, \mathrm{H}_{8}$ or $\left.\mathrm{H}_{9}\right), 3.42$ and 3.22 and $2.97\left(3 \mathrm{x}\right.$ brs, $3 \mathrm{H}, \mathrm{H}_{1}, \mathrm{H}_{6}$ and $\left.\mathrm{H}_{7}\right), 2.80\left(\mathrm{dd}, \mathrm{J}_{1,2}=\right.$ $\left.\mathrm{J}_{2,6}=5.1 \mathrm{~Hz}, 1 \mathrm{H}, \mathrm{H}_{2}\right), 1.74$ and $1.63 \mathrm{AB} \times 2\left(2 \times \mathrm{d}, \mathrm{J}_{10 \mathrm{a}, 10 \mathrm{~s}}=8.4 \mathrm{~Hz}, 2 \mathrm{H}, \mathrm{H}_{10 \mathrm{a}}\right.$ and $\left.\mathrm{H}_{10 \mathrm{~s}}\right)$. GCEI/MS: $\mathrm{m} / \mathrm{e}(\%)$ $146\left(84, \mathrm{M}^{+}\right), 118\left(33, \mathrm{M}^{+}-\mathrm{CO}\right), 81\left(13, \mathrm{M}^{+}+1-\mathrm{C}_{5} \mathrm{H}_{6}\right), 66\left(100, \mathrm{C}_{5} \mathrm{H}_{6}{ }^{+}\right)$.

13: ${ }^{1} \mathrm{H}-\mathrm{NMR}\left(400 \mathrm{MHz}, \mathrm{CDCl}_{3}\right): \delta 7.57\left(\mathrm{dd}, \mathrm{J}_{4,5}=5.7 \mathrm{~Hz}, \mathrm{~J}_{5,6}=2.6 \mathrm{~Hz}, 1 \mathrm{H}, \mathrm{H}_{5}\right), 6.29 \mathrm{~A}$ of $\mathrm{AB}\left(\mathrm{dd}, \mathrm{J}_{8,9}=5.5\right.$ $\mathrm{Hz}, \mathrm{J}_{1.9}$ resp. $\mathrm{J}_{7,8}=3.1 \mathrm{~Hz}, 1 \mathrm{H}, \mathrm{H}_{8}$ or $\left.\mathrm{H}_{9}\right), 6.27\left(\mathrm{dd}, \mathrm{J}_{4.5}=5.7 \mathrm{~Hz}, \mathrm{~J}_{4.6}=1.5 \mathrm{~Hz}, 1 \mathrm{H}, \mathrm{H}_{4}\right), 6.22 \mathrm{~B}$ of $\mathrm{AB}(\mathrm{dd}$, $\mathrm{J}_{8,9}=5.5 \mathrm{~Hz}, \mathrm{~J}_{1,9}$ resp. $\mathrm{J}_{7,8}=3.0 \mathrm{~Hz}, 1 \mathrm{H}, \mathrm{H}_{8}$ or $\mathrm{H}_{9}$ ), 2.93 (brs, $1 \mathrm{H}, \mathrm{H}_{1}$ ), 2.87 (brs, $1 \mathrm{H}, \mathrm{H}_{6}$ ), $2.72\left(\right.$ brs, $1 \mathrm{H}, \mathrm{H}_{7}$ ), $2.27\left(\mathrm{~d}, \mathrm{~J}_{2,6}=5.0 \mathrm{~Hz}, 1 \mathrm{H}, \mathrm{H}_{2}\right), 1.41\left(\mathrm{dt}, \mathrm{J}_{\mathrm{a}, \mathrm{b}}=9.4 \mathrm{~Hz}, \mathrm{~J}=1.5 \mathrm{~Hz}, 1 \mathrm{H}, \mathrm{H}_{10 \mathrm{a}}\right.$ or $\left.\mathrm{H}_{10 \mathrm{~s}}\right), 1.30\left(\mathrm{~d}, 1 \mathrm{H}, \mathrm{H}_{10 \mathrm{a}}\right.$ or $\mathrm{H}_{10 \mathrm{~s}}$ ). GCEI/MS: $\mathrm{m} / \mathrm{e}(\%) 146\left(64, \mathrm{M}^{+}\right), 118\left(19, \mathrm{M}^{+}-\mathrm{CO}\right), 81\left(7, \mathrm{M}^{+}+1-\mathrm{C}_{5} \mathrm{H}_{6}\right), 66\left(100, \mathrm{C}_{5} \mathrm{H}_{6}{ }^{+}\right)$.

endo-Tricyclo[5.2.1. $0^{2,6}$ deca-2(6),8-dien-3-one 5 by oxidative elimination of $7 \mathrm{c}$

A solution of $\underline{7 c}(180 \mathrm{mg}, 0.6 \mathrm{mmol})$ in methanol $(30 \mathrm{ml})$ was treated with a solution of sodium periodate ( $180 \mathrm{mg}$ in $2 \mathrm{ml} \mathrm{H}_{2} \mathrm{O}$ ) at ca. $5^{\circ} \mathrm{C}$ (ice water) with stirring. After $20 \mathrm{~min}$., the solution was filtered and the remaining solid washed with ethyl acetate. The combined organic phase were evaporated and subjected to flash chromatography (n-hexane /EtOAc $=4 / 1)$ to give pure $5(65 \mathrm{mg}, 75 \%)$ as a colorless oil.

\section{Rearrangement of 5 to 1 and 13}

A solution of $\underline{\mathbf{5}}(30 \mathrm{mg})$ in THF $(1 \mathrm{ml})$ was treated with DBU (5 drops) and stirred at room temp. for 3 days. The reaction mixture was poured into ether $(50 \mathrm{ml})$ and washed with brine. Drying $\left(\mathrm{NaSO}_{4}\right)$ and concentration gave a product mixture $(30 \mathrm{mg})$. GC (comparison with known compounds $\underline{1}$ and $\underline{\mathbf{1 3}}$ ) showed that starting material $\underline{\mathbf{5}}$ had disappeared and rearranged quantitatively to a mixture of $\underline{\mathbf{1}}$ and $\underline{\mathbf{1 3}}$ in a $8: 3$ ratio. Further evidence for the formation of $\underline{1}$ and $\underline{\mathbf{1 3}}$ was obtained from ${ }^{1} \mathrm{H}-\mathrm{NMR}$ and GC-MS analyses.

\section{General procedure A for cuprate addition to $3 \mathrm{c}$ :}

A solution of RLi (ca. $1.5 \mathrm{mmol}$ ) in hexane was gradually added to a suspension of dry CuI ( $200 \mathrm{mg}, 1$ $\mathrm{mmol}$ ) in dry ether at temp. below $0{ }^{\circ} \mathrm{C}$ (ice-salt) in a nitrogen atmosphere. After stirring for $15 \mathrm{~min}$. at this temp., the mixture was cooled to $-78^{\circ} \mathrm{C}$. A solution of $\underline{3 \mathrm{c}}(0.5 \mathrm{mmol})$ in ether was then added. The mixture was stirred at $-78{ }^{\circ} \mathrm{C}$ until the reaction was complete according to TLC (ca. $30 \mathrm{~min}$.), then quenched with aqueous ammonium chloride and the aqueous phase extracted with ether $(3 x)$. The combined organic phases were washed with water $(3 \mathrm{x})$, dried $\left(\mathrm{Na}_{2} \mathrm{SO}_{4}\right)$ and the solvent evaporated under reduced pressure. Analytical samples were obtained by flash chromatography and/or crystallization.

\section{endo-5-Methyl-exo-6-phenylselenyl-endo-tricyclo[5.2.1.0 $\left.0^{2,6}\right]$ deca-8-en-3-one 15a}

Following the general procedure A [MeLi $(1 \mathrm{ml}$ of $1.6 \mathrm{M}$ solution in hexane, $1.6 \mathrm{mmol}), \mathrm{CuI}(200 \mathrm{mg}, 1$ $\mathrm{mmol}), \underline{3 c}(150 \mathrm{mg}, 0.5 \mathrm{mmol})]$, gave, after work-up and flash chromatography (n-hexane $/ E t O A c=20 / 1)$, $140 \mathrm{mg}(89 \%)$ of $15 \mathbf{a}$ as a white solid.

15a: m.p.: 61-62 ${ }^{\circ} \mathrm{C}$ (diisopropylether). ${ }^{1} \mathrm{H}-\mathrm{NMR}\left(400 \mathrm{MHz}, \mathrm{CDCl}_{3}\right): \delta 7.66-7.29(\mathrm{~m}, 5 \mathrm{H}, \mathrm{Ph}-\mathrm{H}), 6.31 \mathrm{~A}$ of $\mathrm{AB}\left(\mathrm{dd}, \mathrm{J}_{8,9}=5.6 \mathrm{~Hz}, \mathrm{~J}_{1,9}\right.$ resp. $\mathrm{J}_{7.8}=3.0 \mathrm{~Hz}, 1 \mathrm{H}, \mathrm{H}_{8}$ or $\left.\mathrm{H}_{9}\right), 6.12 \mathrm{~B}$ of $\mathrm{AB}\left(\mathrm{dd}, \mathrm{J}_{8,9}=5.6 \mathrm{~Hz}, \mathrm{~J}_{1,9}\right.$ resp. $J_{7,8}=2.9 \mathrm{~Hz}, 1 \mathrm{H}, \mathrm{H}_{8}$ or $\left.\mathrm{H}_{9}\right), 3.27$ and $3.12\left(2 \mathrm{x}\right.$ brs, $3 \mathrm{H}, \mathrm{H}_{1}, \mathrm{H}_{2}$ and $\left.\mathrm{H}_{7}\right), 2.81-2.71\left(\mathrm{~m}, 1 \mathrm{H}, \mathrm{H}_{5}\right), 2.39 \mathrm{~A}$ of $A B\left(d, J_{10 a, s}=8.6 \mathrm{~Hz}, 1 \mathrm{H}, \mathrm{H}_{10 \mathrm{~s}}\right), 2.08 \mathrm{~A}$ of $\mathrm{AB}\left(\mathrm{dd}, \mathrm{J}_{4 \mathrm{x}, 4 \mathrm{n}}=18.4 \mathrm{~Hz}, \mathrm{~J}_{4 \mathrm{x} .5}=9.5 \mathrm{~Hz}, 1 \mathrm{H}, \mathrm{H}_{4 \mathrm{x}}\right), 1.78 \mathrm{~B}$ of $\mathrm{AB}$ 
(dd, $\left.\mathrm{J}_{4 \mathrm{x}, 4 \mathrm{n}}=18.4 \mathrm{~Hz}, \mathrm{~J}_{4 \mathrm{n}, 5}=12.5 \mathrm{~Hz}, \mathrm{H}_{4 \mathrm{n}}\right), 1.76 \mathrm{~B}$ of $\mathrm{AB}\left(\mathrm{d}, \mathrm{J}_{10 \mathrm{a}, 5}=8.6 \mathrm{~Hz}, 1 \mathrm{H}, \mathrm{H}_{10 \mathrm{a}}\right), 0.98\left(\mathrm{~d}, 3 \mathrm{H}, \mathrm{CH}_{3}\right)$. ${ }^{13} \mathrm{C}$-NMR (100 MHz, $\mathrm{CDCl}_{3}$ ): $\delta 218.8$ (quat.), 137.7/137.5/136.0/129.2/129.1 (tert.), 128.2/63.6 (quat.), 62.8 (tert.), 53.4 (sec.), 52.4 (tert.), 49.4 (sec.), 48.3 (tert.), 39.7 (tert.), 14.6 (prim.). IR $\left(\mathrm{CH}_{2} \mathrm{Cl}_{2}\right): v$ 3080-3020 (C-H, unsat.), 3010-2860 (C-H, sat.), $1730(\mathrm{C}=\mathrm{O}) \mathrm{cm}^{-1}$. EI/MS: m/e (\%) $318\left(9, \mathrm{M}^{+}\right), 252(77$, $\left.\mathrm{M}^{+}-\mathrm{C}_{5} \mathrm{H}_{6}\right), 161\left(45, \mathrm{M}^{+}-\mathrm{SePh}\right), 133\left(59, \mathrm{M}^{+}-\mathrm{SePh}-\mathrm{CO}\right), 95\left(100, \mathrm{M}^{+}-\mathrm{SePh}-\mathrm{C}_{5} \mathrm{H}_{6}\right), 66\left(53, \mathrm{C}_{5} \mathrm{H}_{6}{ }^{+}\right)$. EI/HRMS m/e: 318.0524 [calc.for $\mathrm{C}_{17} \mathrm{H}_{18} \mathrm{O}^{80} \mathrm{Se}\left(\mathrm{M}^{+}\right)$: 318.0523 ].

endo-5-n-Butyl-exo-6-phenylselenvl-endo-tricyclo[5.2.1.0 $\left.0^{2,6}\right]$ deca-8-en-3-one 15b

Following the general procedure A [ $\mathrm{n}-\mathrm{BuLi}(1 \mathrm{ml}$ of $1.6 \mathrm{M}$ solution in hexane, $1.6 \mathrm{mmol}), \mathrm{CuI}(200 \mathrm{mg}, 1$ $\mathrm{mmol}), \underline{3 \mathrm{c}}(150 \mathrm{mg}, 0.5 \mathrm{mmol})]$, gave, after work-up and flash chromatography ( $\mathrm{n}$-hexane $/ \mathrm{EtOAc}=20 / 1$ ), $155 \mathrm{mg}(86 \%)$ of $\underline{15 b}$.

15b: ${ }^{1} \mathrm{H}-\mathrm{NMR}\left(400 \mathrm{MHz}, \mathrm{CDCl}_{3}\right): \delta 7.66-7.29(\mathrm{~m}, 5 \mathrm{H}, \mathrm{Ph}-\mathrm{H}), 6.27 \mathrm{~A}$ of $\mathrm{AB}\left(\mathrm{dd}, \mathrm{J}_{8,9}=5.6 \mathrm{~Hz}, \mathrm{~J}_{1,9}\right.$ resp. $\mathrm{J}_{7,8}=3.1 \mathrm{~Hz}, 1 \mathrm{H}, \mathrm{H}_{8}$ or $\mathrm{H}_{9}$ ), $6.09 \mathrm{~B}$ of $\mathrm{AB}\left(\mathrm{dd}, \mathrm{J}_{8,9}=5.6 \mathrm{~Hz}, \mathrm{~J}_{1,9}\right.$ resp. $\mathrm{J}_{7,8}=2.9 \mathrm{~Hz}, 1 \mathrm{H}, \mathrm{H}_{8}$ or $\mathrm{H}_{9}$ ), 3.25 and $3.14\left(2 \mathrm{x}\right.$ brs, $2 \mathrm{H}, \mathrm{H}_{1}$ and $\left.\mathrm{H}_{7}\right), 3.11\left(\mathrm{~d}, \mathrm{~J}_{1,2}=4.9 \mathrm{~Hz}, 1 \mathrm{H}, \mathrm{H}_{2}\right), 2.63-2.55\left(\mathrm{~m}, 1 \mathrm{H}, \mathrm{H}_{5}\right), 2.37 \mathrm{~A}$ of $\mathrm{AB}(\mathrm{d}$, $\left.\mathrm{J}_{10 \mathrm{a}, \mathrm{s}}=8.6 \mathrm{~Hz}, 1 \mathrm{H}, \mathrm{H}_{10 \mathrm{~s}}\right), 2.11 \mathrm{~A}$ of $\mathrm{AB}\left(\mathrm{dd}, \mathrm{J}_{4 \mathrm{x}, 4 \mathrm{n}}=18.4 \mathrm{~Hz}, \mathrm{~J}_{4 \mathrm{x}, 5}=9.5 \mathrm{~Hz}, 1 \mathrm{H}, \mathrm{H}_{4 \mathrm{x}}\right.$ ), 1.70 B of $\mathrm{AB}$ (dd, $\left.\mathrm{J}_{4 \mathrm{x}, 4 \mathrm{n}}=18.4 \mathrm{~Hz}, \mathrm{~J}_{4 \mathrm{n}, 5}=12.0 \mathrm{~Hz}, 1 \mathrm{H}, \mathrm{H}_{4 \mathrm{n}}\right), 1.75 \mathrm{~B}$ of $\mathrm{AB}\left(\mathrm{d}, \mathrm{J}_{10 \mathrm{a}, \mathrm{s}}=8.6 \mathrm{~Hz}, 1 \mathrm{H}, \mathrm{H}_{10 \mathrm{a}}\right), 1.58-1.00(\mathrm{~m}, 6 \mathrm{H}$, $-\left(\mathrm{CH}_{2}\right)_{3}$ ), 0.84 (t, $3 \mathrm{H}, \mathrm{CH}_{3}$ ). ${ }^{13} \mathrm{C}-\mathrm{NMR}\left(100 \mathrm{MHz}, \mathrm{CDCl}_{3}\right): \delta 218.7$ (quat.), 137.7/137.2/136.2/129.1 (tert.), 128.2/63.2 (quat.), 62.5 (tert.), 53.3 (sec.), 52.6 (tert.), 48.0 (tert.), 47.7 (sec.), 45.4 (tert.), 31.1/30.3/22.7 (sec), 14.0 (prim.). IR $\left(\mathrm{CH}_{2} \mathrm{Cl}_{2}\right):$ v 3080-3020 (C-H, unsat.), 3010-2860 (C-H, sat.), 1720 $(\mathrm{C}=\mathrm{O}) \mathrm{cm}^{-1} . \quad$ EI/MS: m/e (\%) $360\left(3, \mathrm{M}^{+}\right), 294\left(100, \mathrm{M}^{+}-\mathrm{C}_{5} \mathrm{H}_{6}\right), 203\left(55, \mathrm{M}^{+} \mathrm{SePh}\right), 175$ (37, $\left.\mathrm{M}^{+}-\mathrm{SePh}-\mathrm{CO}\right), 137\left(68, \mathrm{M}^{+}-\mathrm{SePh}-\mathrm{C}_{5} \mathrm{H}_{6}\right), 66\left(51, \mathrm{C}_{5} \mathrm{H}_{6}{ }^{+}\right)$. EI/HRMS m/e: 360.0991 [calc.for $\mathrm{C}_{20} \mathrm{H}_{24} \mathrm{O}^{80} \mathrm{Se}$ $\left(\mathrm{M}^{+}\right)$: 360.0992].

endo-5-t-Butyl-exo-6-phenylselenyl-endo-tricyclo/5.2.1.0 $\left.0^{2.6}\right]$ deca-8-en-3-one 15c

Following the general procedure A [t-BuLi $(1 \mathrm{ml}$ of $1.6 \mathrm{M}$ solution in hexane, $1.6 \mathrm{mmol}), \mathrm{CuI}(200 \mathrm{mg}, 1$ $\mathrm{mmol}), 3 \mathrm{c}(150 \mathrm{mg}, 0.5 \mathrm{mmol})]$, gave, after work-up and flash chromatography (n-hexane $/ \mathrm{EtOAc}=20 / 1)$, $45 \mathrm{mg}(25 \%)$ of $\underline{15 \mathrm{c}}$.

15c: ${ }^{1} \mathrm{H}-\mathrm{NMR}\left(400 \mathrm{MHz}, \mathrm{CDCl}_{3}\right): \delta 7.66-7.29(\mathrm{~m}, 5 \mathrm{H}, \mathrm{Ph}-\mathrm{H}), 6.36 \mathrm{~A}$ of $\mathrm{AB}\left(\mathrm{dd}, \mathrm{J}_{8,9}=5.6 \mathrm{~Hz}, \mathrm{~J}_{1,9}\right.$ resp. $\mathrm{J}_{7,8}=3.0 \mathrm{~Hz}, 1 \mathrm{H}, \mathrm{H}_{8}$ or $\mathrm{H}_{9}$ ), $6.13 \mathrm{~B}$ of $\mathrm{AB}\left(\mathrm{dd}, \mathrm{J}_{8,9}=5.6 \mathrm{~Hz}, \mathrm{~J}_{1,9}\right.$ resp. $\mathrm{J}_{7,8}=2.9 \mathrm{~Hz}, 1 \mathrm{H}, \mathrm{H}_{8}$ or $\mathrm{H}_{9}$ ), 3.34 (brs, $1 \mathrm{H}, \mathrm{H}_{1}$ or $\left.\mathrm{H}_{7}\right), 3.18\left(\mathrm{~d}, \mathrm{~J}_{1,2}=5.1 \mathrm{~Hz}, 1 \mathrm{H}, \mathrm{H}_{2}\right), 3.12$ (brs, $1 \mathrm{H}, \mathrm{H}_{1}$ or $\left.\mathrm{H}_{7}\right), 2.77\left(\mathrm{dd}, \mathrm{J}_{4 \mathrm{n}, 5}=12.9 \mathrm{~Hz}, \mathrm{~J}_{4 \mathrm{x}, 5}=10.3\right.$ $\left.\mathrm{Hz}, 1 \mathrm{H}, \mathrm{H}_{5}\right), 2.63 \mathrm{~A}$ of $\mathrm{AB}\left(\mathrm{d}, \mathrm{J}_{10 \mathrm{a}, \mathrm{s}}=8.6 \mathrm{~Hz}, 1 \mathrm{H}, \mathrm{H}_{10 \mathrm{~s}}\right), 1.97\left(\mathrm{~d}, \mathrm{~J}={ }_{4 \mathrm{x} .5} 10.3 \mathrm{~Hz}, 1 \mathrm{H}, \mathrm{H}_{4 \mathrm{x}}\right), 1.96(\mathrm{~d}$, $\left.\mathrm{J}_{4 \mathrm{n}, 5}=12.9 \mathrm{~Hz}, 1 \mathrm{H}, \mathrm{H}_{4 \mathrm{n}}\right), 1.79 \mathrm{~B}$ of $\mathrm{AB}\left(\mathrm{d}, \mathrm{J}_{10 \mathrm{a}, \mathrm{s}}=8.6 \mathrm{~Hz}, 1 \mathrm{H}, \mathrm{H}_{10 \mathrm{a}}\right), 1.13\left(\mathrm{~s}, 9 \mathrm{H}, \mathrm{CH}_{3}\right) .{ }^{13} \mathrm{C}-\mathrm{NMR}(100$ $\mathrm{MHz}, \mathrm{CDCl}_{3}$ ): $\delta 218.7$ (quat.), 137.7/137.1 (tert.), 129.5 (quat.), 129.3/129.0 (tert.), 62.8 (quat.), 62.2 (tert.), 54.8 (sec.), 54.1/53.6/46.8 (tert.), 44.6 (sec.), 33.7 (quat.), 45.4 (tert.), 30.7 (prim.). IR $\left(\mathrm{CH}_{2} \mathrm{Cl}_{2}\right.$ ): v 3080-3020 (C-H, unsat.), 3010-2860 (C-H, sat.), $1720(\mathrm{C}=\mathrm{O}) \mathrm{cm}^{-1}$. EI/MS: m/e (\%) 360 (4, $\left.\mathrm{M}^{+}\right), 294$ (7, $\left.\mathrm{M}^{+}-\mathrm{C}_{5} \mathrm{H}_{6}\right), 203\left(66, \mathrm{M}^{+}-\mathrm{SePh}\right), 137\left(35, \mathrm{M}^{+}-\mathrm{SePh}-\mathrm{C}_{5} \mathrm{H}_{6}\right), 66\left(11, \mathrm{C}_{5} \mathrm{H}_{6}{ }^{+}\right)$. EI/HRMS m/e: 360.0991 [calc.for $\mathrm{C}_{20} \mathrm{H}_{24} \mathrm{O}^{80} \mathrm{Se}\left(\mathrm{M}^{+}\right): 360.0992$ ].

endo-5-Phenyl-exo-6-phenylselenyl-endo-tricyclo[5.2.1.0 $0^{2.6} \mathrm{Jdeca-8-en-3-one} \mathrm{15d}$ and exo-3-phenyl-6phenylselenyl-endo-tricyclo/5.2.1.0 $\left.0^{2.6}\right]$ deca-4,8-dien-3-ol

Following the general procedure A [PheLi $(1.5 \mathrm{ml}$ of $2 \mathrm{M}$ solution in hexane, $3 \mathrm{mmol}), \mathrm{CuI}(200 \mathrm{mg}, 1$ 
$\mathrm{mmol}$ ), $\underline{3 \mathrm{c}}$ (150 mg, $0.5 \mathrm{mmol})$ ], gave, after work-up and flash chromatography (n-hexane $/ E$ tOAc $=20 / 1$ ), $170 \mathrm{mg}(89 \%)$ of a mixture of $\underline{\mathbf{1 5 d}}$ and $\underline{\mathbf{1}} \mathbf{2 - p r o d u c t}$ in $4: 1$ ratio.

15d: ${ }^{1} \mathrm{H}-\mathrm{NMR}\left(400 \mathrm{MHz}, \mathrm{CDCl}_{3}\right): \delta 7.66-7.29(\mathrm{~m}, \mathrm{Ph}-\mathrm{H}), 6.05 \mathrm{~A}$ of $\mathrm{AB}\left(\mathrm{dd}, \mathbf{J}_{8,9}=5.6 \mathrm{~Hz}, \mathbf{J}_{1,9}\right.$ resp. $\mathrm{J}_{7,8}=2.9 \mathrm{~Hz}, 1 \mathrm{H}, \mathrm{H}_{8}$ or $\mathrm{H}_{9}$ ), $5.69 \mathrm{~B}$ of $\mathrm{AB}\left(\mathrm{dd}, \mathrm{J}_{8,9}=5.6 \mathrm{~Hz}, \mathrm{~J}_{1.9}\right.$ resp. $\mathrm{J}_{7,8}=3.2 \mathrm{~Hz}, 1 \mathrm{H}, \mathrm{H}_{8}$ or $\mathrm{H}_{9}$ ), 3.99 (dd, $\left.\mathrm{J}=9.5 \mathrm{~Hz}, \mathrm{~J}=12.1 \mathrm{~Hz}, 1 \mathrm{H}, \mathrm{H}_{5}\right), 3.42\left(\mathrm{~d}, \mathrm{~J}_{1,2}=3.61 \mathrm{~Hz}, 1 \mathrm{H}, \mathrm{H}_{2}\right), 3.30$ and $3.02\left(2 \mathrm{x}\right.$ brs, $2 \mathrm{H}, \mathrm{H}_{1}$ and $\left.\mathrm{H}_{7}\right), 2.54$ $A$ of $A B\left(d d, J_{4 x, 4 n}=18.1 \mathrm{~Hz}, \mathrm{~J}_{4 \mathrm{x}, 5}=12.1 \mathrm{~Hz}, 1 \mathrm{H}, \mathrm{H}_{4 \mathrm{x}}\right), 2.35 \mathrm{~A}$ of $\mathrm{AB}\left(\mathrm{d}, \mathrm{J}_{10 \mathrm{a}, \mathrm{s}}=8.6 \mathrm{~Hz}, 1 \mathrm{H}, \mathrm{H}_{10 \mathrm{~s}}\right), 2.25 \mathrm{~B}$ of $\mathrm{AB}\left(\mathrm{dd}, \mathrm{J}_{4 \mathrm{x}, 4 \mathrm{n}}=18.1 \mathrm{~Hz}, \mathrm{~J}_{4 \mathrm{n}, 5}=9.5 \mathrm{~Hz}, 1 \mathrm{H}, \mathrm{H}_{4 \mathrm{n}}\right), 1.63 \mathrm{~B}$ of $\mathrm{AB}\left(\mathrm{d}, \mathrm{J}_{10 \mathrm{a}, \mathrm{s}}=8.6 \mathrm{~Hz}, 1 \mathrm{H}, \mathrm{H}_{10 \mathrm{a}}\right.$ ).

1,2-product: ' $\mathrm{H}-\mathrm{NMR}\left(400 \mathrm{MHz}, \mathrm{CDCl}_{3}\right.$ ): $\delta 7.66-7.29(\mathrm{~m}, \mathrm{Ph}-\mathrm{H}), 6.31 \mathrm{~A}$ of $\mathrm{AB}\left(\mathrm{dd}, \mathrm{J}_{8,9}=5.4 \mathrm{~Hz}, \mathrm{~J}_{1,9}\right.$ resp. $\mathrm{J}_{7,8}=2.9 \mathrm{~Hz}, 1 \mathrm{H}, \mathrm{H}_{8}$ or $\mathrm{H}_{9}$ ), $5.91 \mathrm{~B}$ of $\mathrm{AB}\left(\mathrm{dd}, \mathrm{J}_{8,9}=5.4 \mathrm{~Hz}, \mathrm{~J}_{1,9}\right.$ resp. $\mathrm{J}_{7,8}=3.4 \mathrm{~Hz}, 1 \mathrm{H}, \mathrm{H}_{8}$ or $\mathrm{H}_{9}$ ), 5.77 and $5.56 \mathrm{AB}\left(2 \mathrm{x} \mathrm{d}, \mathrm{J}_{4,5}=5.5 \mathrm{~Hz}, 2 \mathrm{H}, \mathrm{H}_{4}\right.$ and $\left.\mathrm{H}_{5}\right), 3.15$ and $3.05\left(2 \mathrm{x}\right.$ brs, $2 \mathrm{H}, \mathrm{H}_{1}$ and $\left.\mathrm{H}_{7}\right), 2.97\left(\mathrm{~d}, \mathrm{~J}_{1,2}=4.1\right.$ $\left.\mathrm{Hz}, 1 \mathrm{H}, \mathrm{H}_{2}\right), 2.21 \mathrm{~A}$ of $\mathrm{AB}\left(\mathrm{d}, \mathrm{J}_{10 \mathrm{a}, \mathrm{s}}=8.5 \mathrm{~Hz}, 1 \mathrm{H}, \mathrm{H}_{10 \mathrm{~s}}\right), 1.77 \mathrm{~B}$ of $\mathrm{AB}\left(\mathrm{d}, \mathrm{J}_{10 \mathrm{a}, \mathrm{s}}=8.5 \mathrm{~Hz}, 1 \mathrm{H}, \mathrm{H}_{10 \mathrm{a}}\right), 1.61(\mathrm{~s}$, $1 \mathrm{H}, \mathrm{OH})$.

\section{General procedure $B$ for the synthesis of 18 by oxidative elimination of 15}

A solution of 15 (100 mg, $0.3 \mathrm{mmol})$ in methanol $(5 \mathrm{ml})$ was treated with a solution of sodium periodate (100 mg, $0.5 \mathrm{mmol}$ in $1 \mathrm{ml}$ water) at ca. $5{ }^{\circ} \mathrm{C}$ (ice water) with stirring. After $20 \mathrm{~min}$., the solid was filtered and washed with ethyl acetate. The combined organic phases were evaporated and purified by chromatography.

\section{5-endo-Methyl-tricyclol 5.2.1.0 $\left.0^{2.6}\right]$ deca-2(6),8-en-3-one 18a}

Following the general procedure $\mathrm{B}$ and applying 15a gave, after flash chromatography (n-hexane /EtOAc $=$ $4 / 1$ ), pure $18 \mathrm{a}$ ( $40 \mathrm{mg}, 82 \%$ ) as a colorless oil.

18a: ${ }^{1} \mathrm{H}-\mathrm{NMR}\left(400 \mathrm{MHz}, \mathrm{CDCl}_{3}\right.$ ): $\delta 6.88 \mathrm{~A}$ of $\mathrm{AB}\left(\mathrm{dd}, \mathrm{J}_{8,9}=4.9 \mathrm{~Hz}, \mathrm{~J}_{1,9}\right.$ resp. $\mathrm{J}_{7,8}=3.2 \mathrm{~Hz}, 1 \mathrm{H}, \mathrm{H}_{8}$ or $\mathrm{H}_{9}$ ), $6.77 \mathrm{~B}$ of $\mathrm{AB}\left(\mathrm{dd}, \mathrm{J}_{8,9}=4.9 \mathrm{~Hz}, \mathrm{~J}_{1,9}\right.$ resp. $\mathrm{J}_{7,8}=3.3 \mathrm{~Hz}, 1 \mathrm{H}, \mathrm{H}_{8}$ or $\left.\mathrm{H}_{9}\right), 3.74$ and $3.59\left(2 \mathrm{x}\right.$ brs, $2 \mathrm{H}, \mathrm{H}_{1}$ and $\mathrm{H}_{7}$ ), 3.17-3.10 (m, $\left.1 \mathrm{H}, \mathrm{H}_{5}\right), 2.99 \mathrm{~A}$ of $\mathrm{AB}\left(\mathrm{dd}, \mathrm{J}_{4 \mathrm{x}, \mathrm{ln}}=18.0 \mathrm{~Hz}, \mathrm{~J}_{4 \mathrm{x}, 5}=5.7 \mathrm{~Hz}, 1 \mathrm{H}, \mathrm{H}_{4 \mathrm{x}}\right), 2.44$ and $2.37 \mathrm{AB} \times 2(2 \mathrm{x}$ d, $\left.\mathrm{J}_{10 \mathrm{~s}, 10 \mathrm{a}}=6.7 \mathrm{~Hz}, 2 \mathrm{H}, \mathrm{H}_{10}\right), 2.20 \mathrm{~B}$ of $\mathrm{AB}\left(\mathrm{d}, \mathrm{J}_{4 \mathrm{x}, \mathrm{n}}=18.0 \mathrm{~Hz}, 1 \mathrm{H}, \mathrm{H}_{4 \mathrm{n}}\right), 1.06\left(\mathrm{~d}, \mathrm{~J}=7.2 \mathrm{~Hz}, 3 \mathrm{H}, \mathrm{CH}_{3}\right)$. ${ }^{13} \mathrm{C}-\mathrm{NMR}$ (100 MHz, $\mathrm{CDCl}_{3}$ ): $\delta 206.9 / 198.9 / 158.5$ (quat.), 144.8/141.6 (tert.), 74.1/49.9 (sec.), 49.9/45.0/33.3 (tert.), 17.4 (prim.). IR $\left(\mathrm{CH}_{2} \mathrm{Cl}_{2}\right):$ v 3010-2860 (C-H, sat.), $1675(\mathrm{C}=\mathrm{O}) \mathrm{cm}^{-1}$. EI/MS: m/e (\%) $160\left(64, \mathrm{M}^{+}\right), 105(100), 94\left(29, \mathrm{M}^{+}-\mathrm{C}_{5} \mathrm{H}_{6}\right), 66\left(41, \mathrm{C}_{5} \mathrm{H}_{6}{ }^{+}\right)$. EI/HRMS m/e: 160.0888 [calc.for $\mathrm{C}_{11} \mathrm{H}_{12} \mathrm{O}\left(\mathrm{M}^{+}\right)$: 160.0882$]$.

\section{S-endo-n-Butyl-tricyclo[5.2.1.0.6 $]$ deca-2(6),8-en-3-one $\mathbf{1 8 b}$}

Following the general procedure $\mathrm{B}$ and applying $\mathbf{1 5 \mathbf { b }}$ gave, after flash chromatography (n-hexane /EtOAc $=4 / 1)$, pure $\underline{18 \mathrm{~b}}(44 \mathrm{mg}, 81 \%)$ as a colorless oil.

18b: ${ }^{1} \mathrm{H}-\mathrm{NMR}\left(400 \mathrm{MHz}, \mathrm{CDCl}_{3}\right): \delta 6.82 \mathrm{~A}$ of $\mathrm{AB}\left(\mathrm{dd}, \mathbf{J}_{8,9}=4.9 \mathrm{~Hz}, \mathbf{J}_{1,9}\right.$ resp. $\mathbf{J}_{7,8}=3.1 \mathrm{~Hz}, 1 \mathrm{H}, \mathrm{H}_{8}$ or $\mathrm{H}_{9}$ ), $6.68 \mathrm{~B}$ of $\mathrm{AB}\left(\mathrm{dd}, \mathrm{J}_{8,9}=4.9 \mathrm{~Hz}, \mathrm{~J}_{1,9}\right.$ resp. $\mathrm{J}_{7,8}=3.2 \mathrm{~Hz}, 1 \mathrm{H}, \mathrm{H}_{8}$ or $\mathrm{H}_{9}$ ), 3.66 and $3.54\left(2 \mathrm{x}\right.$ brs, $2 \mathrm{H}, \mathrm{H}_{1}$ and $\mathrm{H}_{7}$ ), $3.0-2.95\left(\mathrm{~m}, \mathrm{l} \mathrm{H}, \mathrm{H}_{5}\right), 2.82 \mathrm{~A}$ of $\mathrm{AB}\left(\mathrm{dd}, \mathrm{J}_{4 \mathrm{x}, \mathrm{n}}=18.0 \mathrm{~Hz}, \mathrm{~J}_{4 \mathrm{x}, 5}\right.$ resp. $\mathrm{J}_{4 \mathrm{n}, 5}=5.7 \mathrm{~Hz}, 1 \mathrm{H}, \mathrm{H}_{4 \mathrm{x}}$ or $\left.\mathrm{H}_{4 \mathrm{n}}\right), 2.37$ and $2.30 \mathrm{AB} \times 2\left(2 \times \mathrm{d}, \mathrm{J}_{10 \mathrm{~s}, 10 \mathrm{a}}=6.7 \mathrm{~Hz}, 2 \mathrm{H}, \mathrm{H}_{10}\right), 2.21 \mathrm{~B}$ of $\mathrm{AB}\left(\mathrm{d}, \mathrm{J}_{4 \mathrm{x}, \mathrm{n}}=18.0 \mathrm{~Hz}, 1 \mathrm{H}, \mathrm{H}_{4 \mathrm{x}}\right.$ or $\left.\mathrm{H}_{4 \mathrm{n}}\right), 1.43(\mathrm{~m}, 1 \mathrm{H}$, one of $\left.\mathrm{CH}_{2} \mathrm{CH}_{2} \mathrm{CH}_{2} \mathrm{CH}_{3}\right), 1.29-1.14(\mathrm{~m}, 5 \mathrm{H}), 0.82\left(\mathrm{~d}, \mathrm{~J}=7.0 \mathrm{~Hz}, 3 \mathrm{H}, \mathrm{CH}_{3}\right) .{ }^{13} \mathrm{C}-\mathrm{NMR}\left(100 \mathrm{MHz}, \mathrm{CDCl}_{3}\right)$ : $\delta$ 206.0/198.9/158.9 (quat.), 144.8/141.6 (tert.), 74.6 (sec.), 50.6 (tert.), 48.0 (sec.), 44.8/39.0 (tert.), 32.5/29.7/22.6 (sec.), 13.9 (prim.). IR $\left(\mathrm{CH}_{2} \mathrm{Cl}_{2}\right):$ v 3010-2860 (C-H, sat.), $1670(\mathrm{C}=\mathrm{O}) \mathrm{cm}^{-1}$. EI/MS: m/e 
(\%) $202\left(27, \mathrm{M}^{+}\right), 91(100), 66\left(17, \mathrm{C}_{5} \mathrm{H}_{6}{ }^{+}\right)$. EV/HRMS m/e: 202.1357 [calc.for $\mathrm{C}_{14} \mathrm{H}_{18} \mathrm{O}\left(\mathrm{M}^{+}\right): 202.1358$ ].

\section{5-endo-t-Butyl-tricyclo[5.2.1.0 $\left.0^{2,6}\right]$ deca-2(6),8-en-3-one 18c}

Following the general procedure $B$ and applying 15c gave, after flash chromatography (n-hexane /EtOAc $=$ $6 / 1$ ), pure $18 \mathrm{c}$ ( $30 \mathrm{mg}, 76 \%$ ) as a white solid.

18c: m.p.: 63.5-65.5 ${ }^{\circ} \mathrm{C}$ (diisopropyl ether). ${ }^{1} \mathrm{H}-\mathrm{NMR}\left(400 \mathrm{MHz}, \mathrm{CDCl}_{3}\right.$ ): $\delta 6.87 \mathrm{~A}$ of $\mathrm{AB}\left(\mathrm{dd}, \mathrm{J}_{8,9}=5.0\right.$ $\mathrm{Hz}, \mathrm{J}_{1,9}$ resp. $\mathrm{J}_{7,8}=3.1 \mathrm{~Hz}, 1 \mathrm{H}, \mathrm{H}_{8}$ or $\left.\mathrm{H}_{9}\right), 6.81 \mathrm{~B}$ of $\mathrm{AB}\left(\mathrm{dd}, \mathrm{J}_{8,9}=5.0 \mathrm{~Hz}, \mathrm{~J}_{1,9}\right.$ resp. $\mathrm{J}_{7,8}=3.1 \mathrm{~Hz}, 1 \mathrm{H}, \mathrm{H}_{8}$ or $\mathrm{H}_{9}$ ), 3.73 and $3.69\left(2 \mathrm{x}\right.$ brs, $2 \mathrm{H}, \mathrm{H}_{1}$ and $\left.\mathrm{H}_{7}\right), 2.92\left(\mathrm{~d}, \mathrm{~J}_{4 \mathrm{x}, 5}\right.$ resp. $\mathrm{J}_{4 \mathrm{n}, 5}=5.8 \mathrm{~Hz}, 1 \mathrm{H}, \mathrm{H}_{5}$ ), $2.72 \mathrm{~A}$ of $\mathrm{AB}$ (dd, $\mathrm{J}_{4 \mathrm{x}, \mathrm{n}}=18.2 \mathrm{~Hz}, \mathrm{~J}_{4 \mathrm{x}, 5}$ resp. $\mathrm{J}_{4 \mathrm{n}, 5}=5.9 \mathrm{~Hz}, 1 \mathrm{H}, \mathrm{H}_{4 \mathrm{x}}$ or $\left.\mathrm{H}_{4 \mathrm{n}}\right), 2.44 \mathrm{~B}$ of $\mathrm{AB}\left(\mathrm{dd}, \mathrm{J}_{4 \mathrm{x}, \mathrm{n}}=18.2 \mathrm{~Hz}, 1 \mathrm{H}, \mathrm{H}_{4 \mathrm{x}}\right.$ or $\mathrm{H}_{4 \mathrm{n}}$ ), 2.45 and $2.37 \mathrm{AB} \times 2\left(2 \times \mathrm{d}, \mathrm{J}_{10 \mathrm{~s}, 1 \mathrm{Oa}_{\mathrm{a}}}=6.8 \mathrm{~Hz}, 2 \mathrm{H}, \mathrm{H}_{10}\right), 0.87\left[\mathrm{~s}, 9 \mathrm{H}, \mathrm{C}\left(\mathrm{CH}_{3}\right)_{3}\right] .{ }^{13} \mathrm{C}-\mathrm{NMR}(100 \mathrm{MHz}$, $\mathrm{CDCl}_{3}$ ): $\delta 204.1 / 199.0 / 160.2$ (quat.), 144.2/141.2 (tert.), 75.6 (sec.), 52.8/50.6/44.6 (tert.), 44.5 (sec.), 34.4 (quat.), 27.9 (prim.). IR $\left(\mathrm{CH}_{2} \mathrm{Cl}_{2}\right): v$ 3010-2860 (C-H, sat.), $1670(\mathrm{C}=\mathrm{O}) \mathrm{cm}^{-1}$. EI/MS: m/e (\%) $203(26$, $\left.\mathrm{M}^{+}+1\right), 146\left(100, \mathrm{M}^{+}+1-\mathrm{CMe}_{3}\right), 66\left(5, \mathrm{C}_{5} \mathrm{H}_{6}{ }^{+}\right), 57\left(56, \mathrm{CMe}_{3}{ }^{+}\right)$. EI/HRMS m/e: 203.1435 [calc.for $\left.\mathrm{C}_{14} \mathrm{H}_{19} \mathrm{O}\left(\mathrm{M}^{+}+1\right): 203.1436\right]$.

\section{5-endo-Phenyl-tricyclo/5.2.1.0 $\left.0^{2,6}\right]$ deca-2(6),8-en-3-one 18d}

Following the general procedure $B$ and applying $15 \mathrm{~d}(150 \mathrm{mg}$, purity is $80 \%)$ gave, after flash chromatography (n-hexane $/$ EtOAc $=4 / 1)$, pure $18 \mathbf{d}(43 \mathrm{mg}, 90 \%)$ as a white solid.

18d: m.p.: 107-109 ${ }^{\circ} \mathrm{C}$ (diisopropyl ether). ${ }^{1} \mathrm{H}-\mathrm{NMR}\left(400 \mathrm{MHz}, \mathrm{CDCl}_{3}\right): \delta 7.31-6.88(2 \mathrm{x} \mathrm{m}, 5 \mathrm{H}, \mathrm{Ph}-\mathrm{H})$, $6.86 \mathrm{~A}$ of $\mathrm{AB}$ (dd, $\mathrm{J}_{8,9}=5.0 \mathrm{~Hz}, \mathrm{~J}_{1,9}$ resp. $\mathrm{J}_{7,8}=3.1 \mathrm{~Hz}, 1 \mathrm{H}, \mathrm{H}_{8}$ or $\mathrm{H}_{9}$ ), $6.36 \mathrm{~B}$ of $\mathrm{AB}\left(\mathrm{dd}, \mathrm{J}_{8,9}=5.0 \mathrm{~Hz}, \mathrm{~J}_{1,9}\right.$ resp. $\mathrm{J}_{7,8}=3.3 \mathrm{~Hz}, 1 \mathrm{H}, \mathrm{H}_{8}$ or $\left.\mathrm{H}_{9}\right), 4.25\left(\mathrm{dd}, \mathrm{J}=6.3 \mathrm{~Hz}, \mathrm{~J}=1.7 \mathrm{~Hz}, 1 \mathrm{H}, \mathrm{H}_{5}\right), 3.85$ and $3.39\left(2 \mathrm{x}\right.$ brs, $2 \mathrm{H}, \mathrm{H}_{1}$ and $\mathrm{H}_{7}$ ), $3.28 \mathrm{~A}$ of $\mathrm{AB}$ (dd, $\mathrm{J}=18.2 \mathrm{~Hz}, \mathrm{~J}=6.3 \mathrm{~Hz}, 1 \mathrm{H}$, one of $\mathrm{H}_{4}$ ), $2.58 \mathrm{~B}$ of $\mathrm{AB}$ (dd, J=18.2 Hz, J=1.7 Hz, $1 \mathrm{H}$, one of of $\left.\mathrm{H}_{4}\right), 2.44\left(\mathrm{~s}, 2 \mathrm{H}, \mathrm{H}_{10}\right) .{ }^{13} \mathrm{C}-\mathrm{NMR}\left(100 \mathrm{MHz}, \mathrm{CDCl}_{3}\right): \delta 203.6 / 198.7 / 158.9$ (quat.), 142.8/142.5 (tert.), 139.9 (quat.), 128.8/127.6/127.0 (tert.), 74.4/51.8 (sec.), 50.3/45.2/44.7 (tert.). IR $\left(\mathrm{CH}_{2} \mathrm{Cl}_{2}\right): v$ 3010-2860 (C-H, sat.), $1680(\mathrm{C}=\mathrm{O}) \mathrm{cm}^{-1}$. EI/MS: m/e (\%) $222\left(100, \mathrm{M}^{+}\right), 156\left(7, \mathrm{M}^{+}-\mathrm{C}_{5} \mathrm{H}_{6}\right), 66(5$, $\mathrm{C}_{5} \mathrm{H}_{6}{ }^{+}$). EI/HRMS m/e: 222.1044 [calc.for $\mathrm{C}_{16} \mathrm{H}_{14} \mathrm{O}\left(\mathrm{M}^{+}\right): 222.1045$ ].

exo-3,4-Epoxy-endo-tricyclo[5.2.1.0 $\left.0^{2,6}\right]$ deca-8-en-5-one-2-carboxylic acid $\mathbf{2 0}$

Ester $19(1.2 \mathrm{~g}, 5 \mathrm{mmol})$ in a solution of $\mathrm{NaOH}$ in methanol $(10 \%, 15 \mathrm{ml})$ was stirred at room temp. for 5 hrs. The mixture was neutralized and concentrated to dryness. Water $(20 \mathrm{ml})$ was added, followed by extraction with ethyl acetate $(3 \mathrm{x})$, then the extracts were washed with water and brine, and dried $\left(\mathrm{Na}_{2} \mathrm{SO}_{4}\right)$. Concentration in vacuo gave $\underline{\mathbf{2 0}}(1 \mathrm{~g}, \sim 100 \%)$ as a white solid.

20: m.p. $144.5-146.5^{\circ} \mathrm{C}$ (diisopropylether/EtOAc). ${ }^{1} \mathrm{H}-\mathrm{NMR}$ (400 MHz, $\mathrm{CDCl}_{3}$ ): $\delta 10.5$ (bs, $1 \mathrm{H}, \mathrm{COOH}$ ), $6.24 \mathrm{~A}$ of $\mathrm{AB}$ (dd, $\mathrm{J}_{8,9}=5.6 \mathrm{~Hz}, \mathrm{~J}_{1,9}$ resp. $\mathrm{J}_{7,8}=3.1 \mathrm{~Hz}, 1 \mathrm{H}, \mathrm{H}_{8}$ or $\mathrm{H}_{9}$ ) $6.19 \mathrm{~B}$ of $\mathrm{AB}\left(\mathrm{dd}, \mathrm{J}_{8,9}=5.6 \mathrm{~Hz}, \mathrm{~J}_{1,9}\right.$ resp. $\mathrm{J}_{7,8}=2.8 \mathrm{~Hz}, 1 \mathrm{H}, \mathrm{H}_{8}$ or $\mathrm{H}_{9}$ ), $3.89\left(\mathrm{dd}, \mathrm{J}_{3,4}=2.2 \mathrm{~Hz}, \mathrm{~J}_{4,6}=1.8 \mathrm{~Hz}, 1 \mathrm{H}, \mathrm{H}_{4}\right), 3.40\left(\mathrm{bs}, 1 \mathrm{H}, \mathrm{H}_{1}\right.$ or $\mathrm{H}_{7}$ ), 3.37 (bs, $1 \mathrm{H}, \mathrm{H}_{1}$ or $\left.\mathrm{H}_{7}\right), 3.34\left(\mathrm{~d}, \mathrm{~J}_{3,4}=2.2 \mathrm{~Hz}, 1 \mathrm{H}, \mathrm{H}_{3}\right), 2.25\left(\mathrm{dd}, \mathrm{J}_{6,7}=4.8 \mathrm{~Hz}, \mathrm{~J}_{4,6}=1.8 \mathrm{~Hz}, 1 \mathrm{H}, \mathrm{H}_{6}\right), 1.87 \mathrm{~A}$ of AB $\left(d, J_{10 a, 10 s}=9.1 \mathrm{~Hz}, 1 \mathrm{H}, \mathrm{H}_{10 \mathrm{~s}}\right), 1.64 \mathrm{~B}$ of $\mathrm{AB}\left(\mathrm{d}, \mathrm{J}_{10 \mathrm{a}, 10 \mathrm{~s}}=9.1 \mathrm{~Hz}, 1 \mathrm{H}, \mathrm{H}_{10 \mathrm{a}}\right)$. IR $\left(\mathrm{CH}_{2} \mathrm{Cl}_{2}\right):$ v 3600-2300 $(\mathrm{COOH}), 3100-3020\left(\mathrm{C}-\mathrm{H}\right.$, unsat.), 3010-2820 (C-H, sat.), 1740 and $1705(\mathrm{C}=\mathrm{O}) \mathrm{cm}^{-1}$. EI/MS: $\mathrm{m} / \mathrm{e}(\%)$ $206\left(2, \mathrm{M}^{+}\right), 161\left(1, \mathrm{M}^{+}-\mathrm{CO}_{2} \mathrm{H}\right), 141\left(72, \mathrm{M}^{+}+1-\mathrm{C}_{5} \mathrm{H}_{6}\right), 66\left(93, \mathrm{C}_{5} \mathrm{H}_{6}{ }^{+}\right)$. EI/HRMS m/e: 206.0580 [calc.for $\mathrm{C}_{11} \mathrm{H}_{10} \mathrm{O}_{4}\left(\mathrm{M}^{+}\right)$: 256.0579]. Found: $\mathrm{C} 64.08, \mathrm{H} 4.81$ (calc.for $\mathrm{C}_{11} \mathrm{H}_{10} \mathrm{O}_{4}: \mathrm{C} 64.08, \mathrm{H} 4.89$ ). 
exo-6-Bromo-exo-4,5-epoxy-endo-tricyclo[5.2.1.0 $\left.0^{2,6}\right]$ deca-8-en-3-one 21

A solution of acid $\underline{\mathbf{2 0}}$ (208 $\mathrm{mg}, 1 \mathrm{mmole})$ in benzene $(5 \mathrm{ml})$ was treated with oxalyl chloride $(0.3 \mathrm{ml})$ and a drop of dimethylformamide. After stirring for $2 \mathrm{hrs}$ at room temp. with protection from moisture, the solvent and excess oxalyl chloride were evaporated and the residual acid chloride was used as such.

A solution of acid chloride ( 1 mmole) in benzene $(5 \mathrm{ml}$ ) was added dropwise $(15 \mathrm{~min}$.) to a dried, stirred suspension of $\mathrm{N}$-hydroxypyridin-2-thione sodium salt $(190 \mathrm{mg}, 1.2 \mathrm{mmole})$ in refluxing bromotrichloromethane while irradiating with a $250 \mathrm{w}$ tungsten lamp in an inert atmosphere. After completion of the addition, the reaction mixture was cooled to room temp. and evaporated to dryness. The crude product was purified by flash chromatography (n-hexane/EtOAc $=9 / 1)$ to give $212(22 \mathrm{mg}, 91 \%)$ as a white solid.

21: m.p. $=109{ }^{\circ} \mathrm{C}$, decomposition (ether). ${ }^{1} \mathrm{H}-\mathrm{NMR}\left(400 \mathrm{MHz}, \mathrm{CDCl}_{3}\right): \delta 6.17-6.12\left(\mathrm{~m}, 2 \mathrm{H}, \mathrm{H}_{8}\right.$ and $\mathrm{H}_{9}$ ), $3.81\left(\mathrm{dd}, \mathrm{J}_{4,5}=2.0 \mathrm{~Hz}, \mathrm{~J}_{2,4}=1.6 \mathrm{~Hz}, 1 \mathrm{H}, \mathrm{H}_{4}\right), 3.57\left(\mathrm{~d}, \mathrm{~J}_{4.5}=2.0 \mathrm{~Hz}, 1 \mathrm{H}, \mathrm{H}_{5}\right.$ ), 3.43 and 3.30 (brs, $2 \mathrm{H}, \mathrm{H}_{1}$ and $\left.\mathrm{H}_{7}\right), 3.05\left(\mathrm{dd}, \mathrm{J}_{1,2}=4.8 \mathrm{~Hz}, \mathrm{~J}_{2,4}=1.6 \mathrm{~Hz}, 1 \mathrm{H}, \mathrm{H}_{2}\right), 2.30 \mathrm{~A}$ of $\mathrm{AB}\left(\mathrm{d}, \mathrm{J}_{10 \mathrm{a}, 10 \mathrm{~s}}=9.2 \mathrm{~Hz}, 1 \mathrm{H}, \mathrm{H}_{10 \mathrm{~s}}\right), 1.95 \mathrm{~B}$ of $\mathrm{AB}$ (dt, $\left.\mathbf{J}_{10 \mathrm{a}, 10 \mathrm{~s}}=9.2 \mathrm{~Hz}, 1 \mathrm{H}, \mathrm{H}_{10 \mathrm{a}}\right)$. IR $\left(\mathrm{CH}_{2} \mathrm{Cl}_{2}\right):$ v 3100-3020 (C-H, unsat.), 3010-2820 (C-H, sat.), 1740 $(\mathrm{C}=\mathrm{O}) \mathrm{cm}^{-1}$. CI/MS: $\mathrm{m} / \mathrm{e}(\%) 242(0.33)$ and $240(0.35)\left(\mathrm{M}^{+}+1\right), 177(13)$ and $175(13)\left(\mathrm{M}^{+}+1-\mathrm{C}_{5} \mathrm{H}_{6}\right), 66$ $\left(100, \mathrm{C}_{5} \mathrm{H}_{6}{ }^{+}\right.$). CI/HRMS m/e: 239.9786 [calc.for $\mathrm{C}_{10} \mathrm{H}_{9} \mathrm{O}_{2}{ }^{79} \mathrm{Br}\left(\mathrm{M}^{+}\right)$: 239.9786].

\section{endo-4,5-Epoxy-endo-6-methoxy-exo-tricyclo[5.2.1.0 $\left.0^{2.6}\right]$ deca-8-en-3-one 23}

Crystalline bromide $\underline{21}$ (120 mg, $0.5 \mathrm{mmol}$ ) was added to a solution of $\mathrm{KOH}(20 \%, 10 \mathrm{ml})$ in methanol with stirring under cooling (ice-water). Stirring was continued until crystalline 21 had dissolved. The mixture was then neutralized and concentrated to dryness. Water $(10 \mathrm{ml})$ was added, the mixture extracted with ether $(3 \mathrm{x})$. The extracts were washed repeatedly with water and brine, dried $\left(\mathrm{Na}_{2} \mathrm{SO}_{4}\right)$ and concentrated in vacuo to give a viscous oil $(95 \mathrm{mg}$ ). Subsequent flash chromatography (n-hexane/EtOAc $=5 / 1$ ) gave pure $\underline{23}$ (75mg, $80 \%)$ as a colorless oil.

23: ${ }^{1} \mathrm{H}-\mathrm{NMR}\left(400 \mathrm{MHz}, \mathrm{CDCl}_{3}\right.$ ): $\delta 6.42 \mathrm{~A}$ of $\mathrm{AB}$ (dd, $\mathrm{J}_{8,9}=5.6 \mathrm{~Hz}, \mathrm{~J}_{1.9}$ resp. $\mathrm{J}_{7.8}=3.1 \mathrm{~Hz}, 1 \mathrm{H}, \mathrm{H}_{8}$ or $\mathrm{H}_{9}$ ), $6.25 \mathrm{~B}$ of $\mathrm{AB}\left(\mathrm{dd}, \mathrm{J}_{8,9}=5.6 \mathrm{~Hz}, \mathrm{~J}_{1,9}\right.$ resp. $\mathrm{J}_{7.8}=2.9 \mathrm{~Hz}, 1 \mathrm{H}, \mathrm{H}_{8}$ or $\mathrm{H}_{9}$ ), $3.94\left(\mathrm{~d}, \mathrm{~J}_{4.5}=2.2 \mathrm{~Hz}, 1 \mathrm{H}, \mathrm{H}_{4}\right), 3.49$ (d, $\left.\mathrm{J}_{4,5}=2.2 \mathrm{~Hz}, 1 \mathrm{H}, \mathrm{H}_{5}\right), 3.39\left(\mathrm{~s}, 3 \mathrm{H}, \mathrm{OCH}_{3}\right), 3.28$ and $3.04\left(2 \mathrm{x}\right.$ bs, $2 \mathrm{H}, \mathrm{H}_{1}$ and $\left.\mathrm{H}_{7}\right), 2.28 \mathrm{~A}$ of $\mathrm{AB}(\mathrm{d}$, $\left.\mathrm{J}_{10 \mathrm{a}, 10 \mathrm{~s}}=9.3 \mathrm{~Hz}, 1 \mathrm{H}, \mathrm{H}_{10 \mathrm{~s}}\right), 2.16\left(\mathrm{~d}, \mathrm{~J}_{2,10 \mathrm{a}}=2.6 \mathrm{~Hz}, 1 \mathrm{H}, \mathrm{H}_{2}\right), 1.53 \mathrm{~B}$ of $\mathrm{AB}\left(\mathrm{ddt}, \mathrm{J}_{10 \mathrm{a}, 10 \mathrm{~s}}=9.3 \mathrm{~Hz}, \mathrm{~J}_{10 \mathrm{a}, 1}=\right.$ $\mathrm{J}_{10 \mathrm{a}, 7}=1.7 \mathrm{~Hz}, \mathrm{~J}_{10 \mathrm{a}, 2}=2.6 \mathrm{~Hz}, 1 \mathrm{H}, \mathrm{H}_{10 \mathrm{a}}$, ). IR $\left(\mathrm{CH}_{2} \mathrm{Cl}_{2}\right): v 3100-3020(\mathrm{C}-\mathrm{H}$, unsat.), 3010-2820 (C-H, sat.), $1735(\mathrm{C}=\mathrm{O}) \mathrm{cm}^{-1}$. Cl/MS: m/e (\%) $192\left(0.3, \mathrm{M}^{+}\right), 161\left(1, \mathrm{M}^{+}-\mathrm{OCH}_{3}\right), 127\left(95, \mathrm{M}^{+}+1-\mathrm{C}_{5} \mathrm{H}_{6}\right), 66(100$, $\mathrm{C}_{5} \mathrm{H}_{6}{ }^{+}$). EL/HRMS m/e: 192.0789 [calc.for $\mathrm{C}_{11} \mathrm{H}_{12} \mathrm{O}_{3}\left(\mathrm{M}^{+}\right)$: 192.0786].

exo-4,5-Epoxy-exo-6-methoxy-endo-tricyclo[5.2.1.0,6/deca-8-en-3-one 25

A solution of $\underline{24}^{4}(100 \mathrm{mg}, 0.57 \mathrm{mmol})$ in dichloromethane $(4 \mathrm{ml})$ and methanol $(4 \mathrm{ml})$ was treated with $\mathrm{NaOH}$ aq. $(0.2 \mathrm{~N}, 2 \mathrm{ml})$ and $\mathrm{H}_{2} \mathrm{O}_{2}(35 \%, 2 \mathrm{ml})$ at room temp. The mixture was stirred for 4 hrs at room temp. Dichloromethane $(50 \mathrm{ml})$ was added and washed with brine. After drying $\left(\mathrm{NaSO}_{4}\right)$ and concentration in vacuo, flash chromatography (n-hexane/EtOAc $=3 / 1)$ gave $\underline{\mathbf{2 5}}(100 \mathrm{mg}, 90 \%)$.

25: ${ }^{1} \mathrm{H}-\mathrm{NMR}\left(400 \mathrm{MHz}, \mathrm{CDCl}_{3}\right): \delta 6.12-6.10\left(\mathrm{~m}, 2 \mathrm{H}, \mathrm{H}_{8}\right.$ and $\left.\mathrm{H}_{9}\right), 3.76-3.75\left(\mathrm{~m}, 1 \mathrm{H}, \mathrm{H}_{4}\right), 3.54(\mathrm{~s}, 3 \mathrm{H}$, $\left.\mathrm{OCH}_{3}\right), 3.39\left(\mathrm{~d}, \mathrm{~J}_{4,5}=2.4 \mathrm{~Hz}, 1 \mathrm{H}, \mathrm{H}_{5}\right), 3.2 \mathrm{l}-3.19\left(\mathrm{~m}, 2 \mathrm{H}, \mathrm{H}_{1}\right.$ and $\left.\mathrm{H}_{7}\right), 2.57\left(\mathrm{dd}, \mathrm{J}_{1,2}=5.2 \mathrm{~Hz}, \mathrm{~J}_{2.4}=1.7 \mathrm{~Hz}\right.$, $\left.1 \mathrm{H}, \mathrm{H}_{2}\right), 2.02 \mathrm{~A}$ of $\mathrm{AB}\left(\mathrm{d}, \mathrm{J}_{10 \mathrm{a}, 10 \mathrm{~s}}=8.7 \mathrm{~Hz}, 1 \mathrm{H}, \mathrm{H}_{10 \mathrm{~s}}\right), 1.78 \mathrm{~B}$ of $\mathrm{AB}\left(\mathrm{dt}, \mathrm{J}_{10 \mathrm{a}, 10 \mathrm{~s}}=8.7 \mathrm{~Hz}, \mathrm{~J}_{10 \mathrm{a} .1}=\mathrm{J}_{10 \mathrm{a} .7}=1.6\right.$ 
$\mathrm{Hz}, 1 \mathrm{H}, \mathrm{H}_{10 \mathrm{a}}$ ). IR $\left(\mathrm{CH}_{2} \mathrm{Cl}_{2}\right):$ v 3100-3020 (C-H, unsat.), 3010-2820 (C-H, sat.), 1730 (C=O) cm ${ }^{-1}$. CI/MS: $\mathrm{m} / \mathrm{e}(\%) 127\left(100, \mathrm{M}^{+}+1-\mathrm{C}_{5} \mathrm{H}_{6}\right), 66\left(100, \mathrm{C}_{5} \mathrm{H}_{6}{ }^{+}\right)$, CI/HRMS m/e: 193.0865 [calc.for $\mathrm{C}_{11} \mathrm{H}_{13} \mathrm{O}_{3}\left(\mathrm{M}^{+}\right)$: 193.0865].

\section{References and notes}

1. (a) Klunder, A.J.H.; Bos, W.; Zwanenburg, B., Tetrahedron Lett., 1981, 22, 4557. (b) Verlaak, J.M.J.; Klunder, A.J.H.; Zwanenburg, B., ibid., 1982, 23, 5463. (c) Klunder, A.J.H.; Huizinga, W.B.; Sessink, P.J.M.; Zwanenburg, B., ibid., 1987, 28, 357. (d) Klunder, A.J.H.; Houwen-Claassen, A.A.M.; Kooy, M.G.; Zwanenburg, B., ibid., 1987, 28, 1329. (e) Lange, J.H.M.; Klunder, A.J.H.; Zwanenburg, B., ibid., 1989, 30, 127. (f) Houwen-Claassen, A.A.M.; Klunder, A.J.H.; Zwanenburg, B., Tetrahedron, 1989, 45, 7134. (g) Klunder, A.J.H.; Zwanenburg, B.; Liu, Z-Y., Tetrahedron Lett., 1991, 32, 3131. (h) Lange, J.H.M.; Klunder, A.J.H.; Zwanenburg, B., Zwanenburg, B., Tetrahedron, 1991, 47, 1509. (i) Zhu, J.; Klunder A.J.H.; Zwanenburg, B., Tetrahedron, 1994, $50,10597$.

2. (a) Grieco, P.A.; Abood, N., J. Org. Chem., 1989, 54, 6008. (b) Takano, S.; Inomata, K.; Ogasawara, K., J. Chem. Soc., Chem. Commun., 1989, 271. (c) Garland, R.B.; Miyano, M.; Pireh, D.; Clare, M.; Finnegan, P.M.; Swenton, L., J. Org. Chem., 1990, 55, 5854. (d) Grieco, P.A.; Abood, N., J. Chem. Soc., Chem. Commun., 1990, 410. (e) Takano, S.; Inomata, K.; Ogasawara, K., ibid., 1990, 1544. (f)(g) Takano, S.; Moriya, M.; Ogasawara, K., Tetrahedron Lett., 1992, 33, 329 and 1909. (h) Liu, Z.Y.; He L.; Zheng, H., Synlett., 1993, 191 . (i)(j) Liu, Z.Y.; Chu, X.J., Tetrahedron Lett., 1993, 34, 349 and 3885. (k) Ogasawara, K., Pure \& Appl. Chem., 1994, 66, 2119.

3. Herz, W.; Iyer, V.S.; Nair, M.G., J. Org. Chem., 1975, 40, 3519. For a modified and improved procedure, see: Klunder, A.J.H.; de Valk, W.C.G.M.; Verlaak, J.M.J.; Schellekens, J.W.M.; Noordik, J.H.; Parthasarathi, V.; Zwanenburg, B., Tetrahedron, 1985, 4I, 963.

4. Zhu, J.; Klunder, A.J.H.; Zwanenburg, B., Tetrahedron Lett., 1993, 34, 3335. Zhu, J.; Klunder, A.J.H.; Zwanenburg, B., preceding paper.

5. Kienzle, F.; Minder, R.E., Helv. Chim. Acta, 1987, 70, 1537.

6. Barton, D.H.R.; Crich, D.; Motherwell, W.B., J. Chem. Soc., Chem. Commun. 1983, 939; Barton, D.H.R.; Lacher, B.; Zard, S.Z., Tetrahedron Lett. 1987, 43, 4321; Barton, D.H.R.; Crich D.; Motherwell, W., Tetrahedron 1985, 41, 3901 .

7. Zhu, J.; Klunder, A.J.H.; Zwanenburg, B., Tetrahedron Lett., 1994, 35, 2787.

8. Use of the services and facilities of the Dutch National NWO/SURF Expertise Center CAOS/CAMM, University of Nijmegen, The Netherlands, under grant numbers SON 326-052 and STW NCH99.1751, is gratefully acknowledged.

9. Larock, R.C., Comprehensive Organic Transformations, VCH Publishers.Inc., New York (1989).

10. Dols, P.M.M.A.; Verstappen, M.M.H.; Klunder, A.J.H.; Zwanenburg, B., Tetrahedron, 1993, 49, 11353.

11. Moers, F.G.; Beurskens, P.T.; Zhu, J.; Klunder, A.J.H., to be published.

12. Houwen-Claassen, A.A.M.; Klunder, A.J.H.; Zwanenburg, B., Tetrahedron, 1989, 45, 7134. Houwen-Claassen, A.A.M.; Klunder, A.J.H.; Zwanenburg, B., Tetrahedron, 1990, 46, 2593.

13. Houwen-Claassen, A.A.M.; Klunder, A.J.H.; Zwanenburg, B.; Beurskens, P.T.; Moers, F.G.; Beurskens, G., Tetrahedron, 1990, 46, 4283.

14. This result is consistent with an early report in which parent cyclopentadienone epoxide was shown to decompose in acidic or basic media, see: Chapmann, O.L.; Hess, T.C., J. Org. Chem., 1979, 44, 962.

15. Comparison of the ${ }^{1}$ HNMR-data of epoxide $\underline{25}$ with those of the tricyclic exo-epoxides $\underline{19}, \underline{20}$ and $\underline{21}$ immediately revealed the exo-configuration of the epoxide function in $\mathbf{2 5}$. In particular the striking correspondence in chemical shifts observed for the $\mathrm{C}_{4}$-endo-protons is convincing. If the epoxide function would have been in the endo-position a significant upfield shift $(>0.6 \mathrm{ppm})$ of the $\mathrm{C}_{4}$-exo-proton should have been observed ${ }^{16}$.

16. Dols, P.P.M.A,; Arnouts, E.G.; Rohaan, J.; Klunder, A.J.H.,; Zwanenburg, B., Tetrahedron 1994, 50 , 3473.

17. Dols, P.P.M.A.; Klunder, A.J.H.; Zwanenburg, B., Tetrahedron, 1994, 50, 8515.

(Received in UK 2 February 1995; revised 17 February 1995; accepted 24 February 1995) 